\title{
Interfaces
}

INTERFACES Image Texte Language

46 | 2021

Jeux de Formats (2)

\section{Reading Queer Irish Performance across Live and Digital Practice}

\section{Katherine Nolan}

\section{(2) OpenEdition}

Journals

Electronic version

URL: https://journals.openedition.org/interfaces/4122

DOI: 10.4000/interfaces.4122

ISSN: 2647-6754

Publisher:

Université de Bourgogne, Université de Paris, College of the Holy Cross

\section{Electronic reference}

Katherine Nolan, "Reading Queer Irish Performance across Live and Digital Practice", Interfaces [Online], 46 | 2021, Online since 15 December 2021, connection on 16 June 2022. URL: http:// journals.openedition.org/interfaces/4122 ; DOI: https://doi.org/10.4000/interfaces.4122

This text was automatically generated on 16 June 2022 .

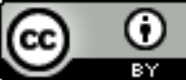

Les contenus de la revue Interfaces sont mis à disposition selon les termes de la Licence Creative Commons Attribution 4.0 International. 


\title{
Reading Queer Irish Performance across Live and Digital Practice
}

\author{
Katherine Nolan
}

\section{Introduction: Life and Performance Under the Image}

1 The image and performance art are intrinsically linked. Whilst the conceptualisation of the nexus between live event and its 'documentation' (Auslander), 'traces' (Jones, Presence in Absentia) or 'records' (Westermann) is subject to ontological debate, it is clear that performance and the image have a tense, contested and on-going relationship. In her 1998 reading of images of early live works of the 1970s, Kathy O'Dell argues that: "While leafing through publications (still by far the predominant way one comes to know about performance art), the viewer participates in a sort of narrative." (14). She describes the tacit experience of handling photographs, asserting that their material qualities produce a "haptic response" that connects the viewer with the live moment (14). It can be inferred from this analysis that the materiality of the image and the framing device that the photograph sits within play a constitutive role in the meaning of the artwork. Digital, and especially social media I argue, is now the dominant form through which performance is received, as still - and, increasingly, moving - image. Whether published by the artist, gallery or spectators, it is difficult to avoid the dissemination of live artworks on digital platforms. The ontology of the image has dramatically changed since O'Dell's reading of performance works through the grain and materiality of the film image reproduced in the low-fi art zine. Under the digital, the image becomes encoded pixels, compressible, transmissible and networked. Image making and online publishing are normalised and taken for granted as everyday activities. In social media platforms such as Instagram, users frame and narrate their lives through on-going posts, from banal images to major life events. In this context the posting of artwork on social media is an apparently incidental - yet meaning making act. However, performance works are read, re-read, and then subsequently re-made and transformed through its circuitry. Thus, how live and image-based practices cross- 
reference and become each other, that is how performance art rubs up against the digital, demands scrutiny.

Driven by commercialisation, technological advances in image-making and publishing have been integrated into daily life, such that life itself becomes a series of events valued for their image-worthiness. Joanna Zylinska describes how life is cut into fragments in our smart phone and social media albums, reconceptualising it as an "imagistic flow" (146). However, this is not a one-way circuit with life feeding into digital media: through these practices life itself has also become photographic (146). Isobel Harbison posits "a new generalised social condition of living and performing 'under the image."' (Harbison 15). She describes not just how we perform as images on a daily basis, but how we are performed by them: the body "affects and is affected by images" (16). She asserts the urgency of artworks that "scrutinize a certain circuitry between the subject, the photographic apparatus and the screen" and the "reciprocity of images and bodies during regular, multiple and multisited encounters." (Harbison 16).

3 Performance as "Inframedium", that is ontologically situated between live/life event and image, is well placed to critically address our radically accelerated, embodied relationship to the image through digital technology (Westerman, n.p.). As a medium that is "between action and image" it speaks to the complex relationship and tensions between life as embodied lived experience and life as image (Westerman, n.p.). Yet the relationship of the live performance to the image is deeply tense and contested. Peggy Phelan's influential writing maintains "Performance's only life is in the present" such that once it is recorded or repeated, it becomes something other than performance (146). This privileges the live event as the only site in which the artwork occurs: such that the image exists only to mobilise the original experience. In contradistinction to this Philip Aulander argues that "no documented work of performance art is performed solely as an end in itself: the performance is always at one level raw material for documentation" (Auslander 31). In this view, in a hypermediated society, all performance ultimately exists to become an image. This speaks to the era of networked social and digital media which seeks to incorporate all life into an image feed.

That is not to elide live performance and the image completely. Amelia Jones maintains that different forms of knowledge are produced through experiences of live works and their documentary traces, neither of which she asserts should be privileged (Jones, Presence in Absentia 12). She contends that even works that are experienced live, beyond the duration of the event, are "viewed through the memory screen...they become documentary in their own right" (12). Thus, live works are understood as texts that circulate within discourse and are subject to on-going acts of interpretation rather than having a fixed meaning (i.e. at the original moment). This view of the meaning of performance works as contingent is furthered by Christopher Bedford, who conceptualises performance as having a "viral ontology". He asserts that performance artworks absorb meaning over time, as they are re-told, re-presented or re-performed (Bedford). Reconciling both Phelan and Jones understandings, he claims that "it is the absence of the event, the absence of an object, that makes the work available for rewriting, and it is this quality that permits the work to travel through time and space, absorbing and assimilating the conditions of history" (86). Performance's virality, its continual re-iteration through re-presentation, explicitly demonstrates that the meaning of cultural representations are themselves unfixed and contingent (on 
context, viewpoint etc). Yet, I argue the visibility of this viral ontology is not given, but dependant on acts of excavating the artwork's historical trajectories. To 'go viral' is to become infectious, to instantly and indiscriminately spread across contexts. In sharable media, which present ever forking routes through which images are decontextualised and recontextualised, new meanings are continually performed. Thus, the trajectories of performance art across meaning making contexts demand to be carefully unpicked, and, I argue, digital and social media contexts require to be read as framing devices and signifiers that are themselves productive of meaning.

5 Munoz asserts the absence/presence mobilised by the time-based nature of performance and its "ephemera" disrupts the binarization of the past and present which sustains a normative heterosexualist temporality (71). Such disruption of linear concepts of time as neatly divided into past/present, is mobilised in Munoz's concept of "queer futurity" and Halberstam's "strange temporalities" that draw on queer lived experiences to disrupt the normative structuring of experiences through heterosexual, naturalised logics (Munoz 18; Halberstam 1). Halberstam asserts that, "Queer subculture produces alternative temporalities by allowing their participants to believe their futures can be imagined according to logics that lie outside of those paradigmatic markers of life experience - namely, birth, marriage, reproduction, and death" (2). In this way the mining of queer lived experiences, and their mobilisation as artistic and critical strategies in performance, can not only account for oppressed, marginalised gendered subjectivities, but also present methods to critique, dismantle and reimagine the naturalised structures that hold normativity and systems of power in place. In the context of pervasive imageness and its instrumentalization by digital capitalism, queer subjectivities mobilised across live and digital performance practices hold promise as vectors of criticality and embodied resistance.

6 This paper will examine the practices of Francis Fay and Day Magee, two Irish, queer and genderqueer identified contemporary artists working in performance practice. I will analyse how they utilise performance across live and digital practice and mobilise social media as both form and framing device. The subject positioned as queer is always already considered at odds with, and othered from, normative heterosexual dominant narratives; they must negotiate their subjectivity from the margins and against the grain, producing powerful critical embodied strategies that challenge the naturalisation of normative subjectivity. Though it should be noted that queerness is not understood as a unified experience and that these examples of queer experience, of white subjectivities socialised as male, whilst marginalised, can themselves exclude other forms of queerness as trans or racialised. Theorists such as Crenshaw and Lorde have argued for the recognition of intersecting categories of oppression, especially race. The recognition that gender is a spectrum, and that a range of intersecting differences operates as oppression is vital. I examine how these artists perform queer subjectivities as identifications with Otherness and indeterminacy through which they refuse to allow queer itself to settle into another fixed category.

7 I have encountered the work of these performers across different sites (gallery, social media platforms, my smartphone roll, digital publications), in various formats (live, image, video), as well as in multiple roles: I write this as a performer, curator and an audience member of live performances, as a user of social media and a colleague of the performers. The experiences, images and memories of these performances are comingled, overlayed and sedimented. My analysis will give an account of these 
practices, understood as readings across multiple media, sites and contexts, and which are underpinned by my subject position, networked to the artists, and as a white, Irish, middle-class, heterosexual, cis-gendered, woman, who does not live, but seeks to understand queer experiences. In this way, I aim to produce a situated account, reading these works as a relational subject, in order to perform their meaning as iterative and contingently produced through the contexts of the performance (art gallery, social/ cultural site) and frames of digital and social media. I examine how the artworks mobilise queer subjectivities as a form of critical intervention and embodied resistance, often sitting in tension with the capitalist drive of digital platforms. Far from being a tangential concern, O'Riordan argues that "LGBTQ+ identities, practices and theories have been mixed up in the emergence, design and constitution of digital technologies" (185). Kara Keeling furthermore asserts, that the application of queer studies and theoretical concepts offers "ways of thinking about new media that disrupt what we know about it" (156). Digital media therefore demands interrogation through a queer lens. I employ these artists' queer practices, articulated as they sit across live and digital contexts, as a means to point to ways in which subjectivity itself is constantly produced across lived experiences of the body and its image in digital interfaces.

\section{Digital Drag: Fay's Queer Dublin Imaginary}

Dispersed through my Instagram and Facebook feed over time, I encounter Fay's smartphone practice that documents his navigations through Dublin, the city where we both live. Travelling by bicycle, he captures what he notices: the Victorian fruit market and its decorative detail, an effigy of the Virgin Mary in the window of a red-brick worker's cottage, a tattered upholstery shop with a conspicuous 'like new' sign (Figure 1). These images depict a gritty, poetic and bawdy street life of Dublin's working-class inner-city in post-colonial, post-Catholic Ireland. As I scroll through Fay's profile, I reencounter his on-going journey: a woman on a park bench sheltering in a sleeping bag; some faint graffiti that declares "hurt people, hurt people"; and a tree ritually strewn with ribbon wishes. On March $21^{\text {st }} 2020$, as COVID-19 emerges, he slides in beside a billboard that announces "Dublin, something big is brewing". These images parade for me the intersecting histories of the city I inhabit and capture the emotional and cultural moment. These images are born of a practice of noticing the unnoticed, repressed and those 'othered' in and by life in this city. In this way, Fay deploys an artistic critical strategy of making visible lived experiences rendered invisible. There is tension perhaps in the photograph's inevitable objectification, which might be interpreted in itself as othering. Yet, Sontag counters such ideas that images of "the pain of others" are only voyeuristic spectacle (110). "Remembering is an ethical act" she argues; we must "let the atrocious images haunt us" (115). Fay's images do not speak of a "desire for mastery" or an assertion of privilege (Alcoff 23-29): they do however refuse to erase the destitute from this imaging of Dublin city. 
Figure 1. Dublin Something Big is Brewing. Screenshot of Instagram post.

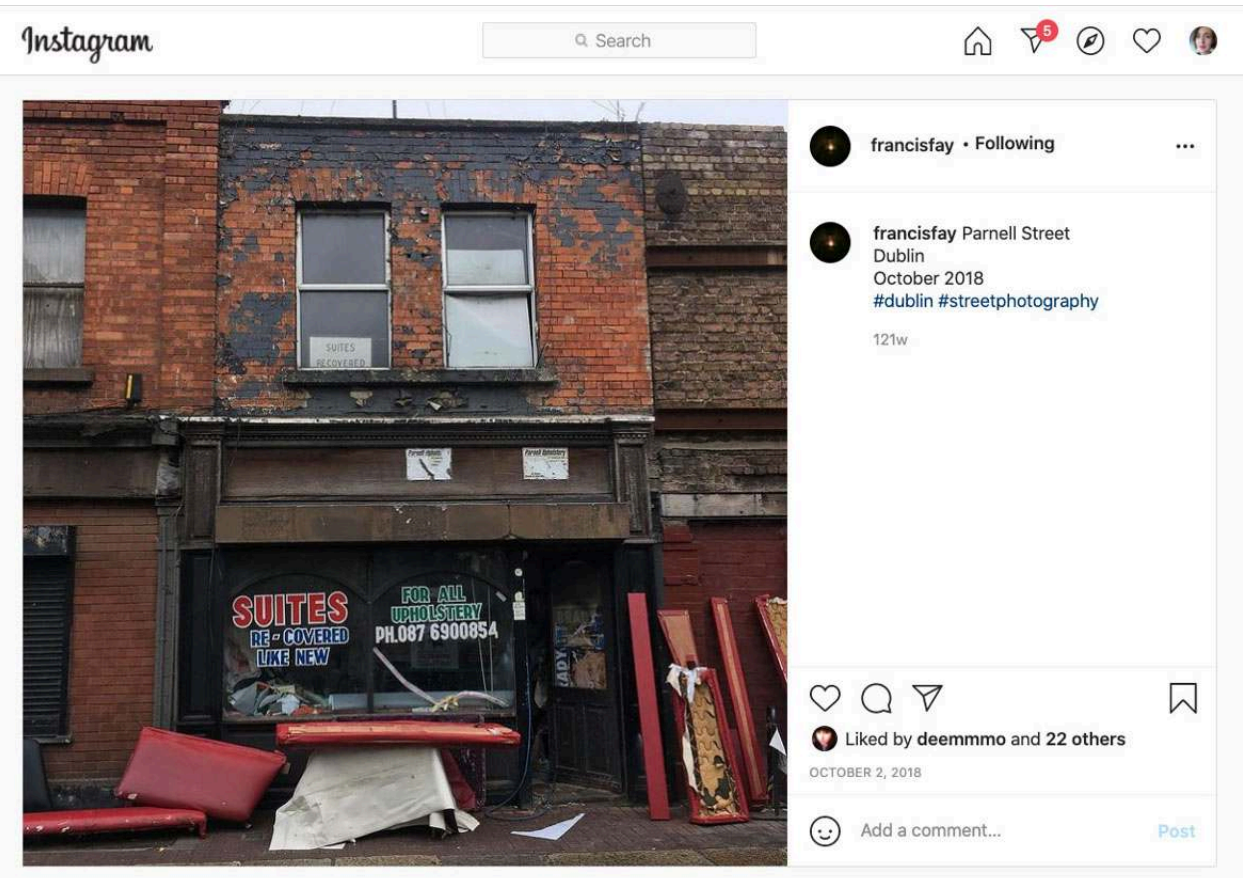

(C) https://www.instagram.com/p/B-ANvXyntwLBCmBluU32rBeo-gsiEtwxXHThOE0/(page accessed 26th of November 2020).

9 Fay's social media documentary practice is interspersed with self-portraits in which his image is overlayed by means of digital collage with imagery found on his journeys through the city: found objects become frames; statues, mannequins and skulls become mirrors; his face merges with a painting of Jesus Christ or a vivid pink flower (Figure 2). His eyes pierce through, heavy with the shadows of high contrast colourisation as if painted. There is both a veiling and an unveiling in the play with the translucent digital layers through which Fay's likeness merges with objects, which produces registers of the image that are both realist and dreamlike, a kind of digital drag. Cowan claims that her concept of "transmedial drag" (moving across forms of media) "creates a sort of pastiche of the 'original,' denaturalizing its status as 'originary"' (n.p.). Fay's performances to camera stake no claim to an original but produce fantastical selves through digital collage that can exist only within the plane of representation and in this way "cast[s] the concept of the real into doubt" (In Between Subjects 17). Masquerading with cultural tropes, he queers their significations, appropriating them through camp incorporation that points to the erasure and prohibition of homosexuality in Irish public discourse. The criminalisation of homosexuality in Ireland until as late as 1993 was used to "justify the suppression of public discussion and manifestations of homosexuality, and to sanction discriminatory practice." (Ryan 6). Fay utilises the digital layer and the unfolding of images in his Instagram feed to bring his image as queer into conversation with street scenes and cultural artefacts. This is a kind of representational claiming of public space that Jones links to defiant street protest cultures of queer activism (In Between Subjects 139). Thus, he deploys this performance/imaging practice as a recuperative strategy that reclaims and queers Dublin city. 
Figure 2. Jesus collage and other images: screenshot from Instagram profile. FAY, Francis.
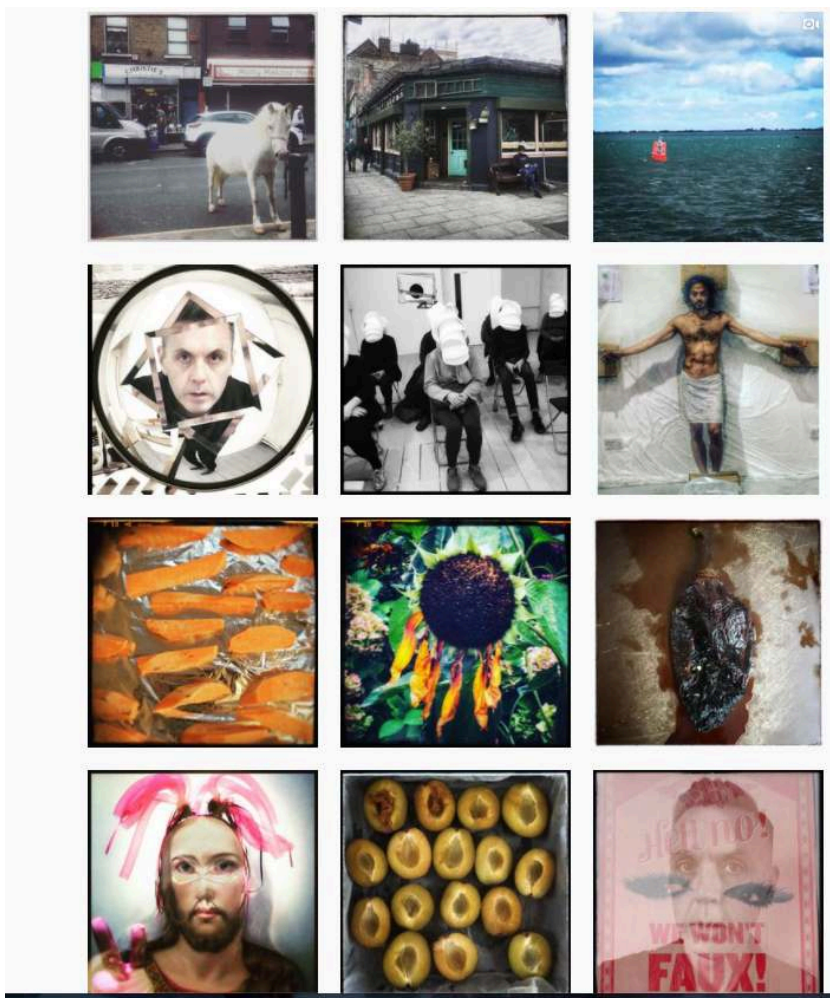

(@[@francisfay] n.d. Instagram Profile. www.instagram.com/francisfay/. (page accessed 26th of November 2020).

In these works, Fay also maps himself relationally to objects, sites and others, and in his Instagram profile these digital drag portraits sit seamlessly alongside his social documentary practice, and documents of live performance. The feed appears at times as gritty document, at others camp carnival. The collage works present an embodied subjectivity that is performed through its contexts, encounters and juxtapositions. It is a practice that images a historically and culturally situated yet fantastical self, in dream-like transposition and transformation. Fay terms this "a Dublin Imaginary" (francisfay.com). Mobilising the capabilities, frames and signification values of digital and social media as part of a wider artistic strategy, his politics is performed, as an elaboration of his live practice. It is a politics of queerness, that seeks to recuperate invisible lived experiences, intimate gestures, and political utterances. He employs the digitally networked image both to signify queerness (as playful camp drag); and employs queerness as a political stance and artistic strategy (noticing, recuperating, and claiming public space).

\section{Staging and Situating Queerness}

11 Fay's self-portraiture can be read against the forms and conventions of social media, as well as those of the history of art, performance and the image. The smartphone-socialmedia nexus has normalised and proliferated self-representation, which was once a form confined to art and photography practices. Indeed the Instagram profile, as curated public account of the self, frames all images within it as a kind of self-portrait. Performance practice is not reducible to self-representation but does intersect with 
and speak to this photographic form. Discussing performance works to camera, Sarah Bright usefully delineates some modes of self-imaging in art practice, differentiating the choreographed/staged from the situationist. The staged, she says, can be epitomised by the elaborate visual choreographies of Matthew Barney (18). The situationist (after Guy Debord et. al) - in which an event or situation is set-up and allowed to unfold unpredictably before the camera - can be seen in Laural Nakadate's video series of tense-ambiguous encounters with middle-aged men in their homes (183). Whilst these categories are useful, there is a risk of them becoming binarized: the situationist, while unpredictable, is nonetheless staged to unfold. Indeed many practices such as Nakadate's call into question the relationship of the staged to the authentic, disrupting them as binary categories. Fay's practice moves fluidly between the staged and the situational holding them in tension with each other, mobilising these modes of performance to complicate concepts of the staged/queer body.

12 This tension between staging and 'situating' is further entangled in the live context. For many, live performance is the unpredictable unfolding of events, witnessed by an audience who experience and validate the precariousness of the shared live moment. This conceptualisation of performance can be traced to Allan Kaprow's highly influential Happenings that sought to "blur the boundary between art and everyday life" through encounters that foregrounded spontaneity and happenstance (Beavan n.p.). Risk and physical and emotional endurance have become synonymous with this unfolding in performance art, as exemplified by influential live work such as Chris Burden's Shoot (1971) where the artist was shot in the arm; and Tehching Hsieh's Cage Piece (1978-79) which saw the artist living in a cage for one year. The endurance of the body of the performer powerfully implicates viewers, relationally entangling them in the ethics and politics of the performer's action. Shalson notes how such endurance work raises "questions about what it means to exist as a body that both acts and is acted upon". Yet, there is a danger that this testing of bodies and this unfolding which is nonetheless staged to unfold - is conflated with the unstaged, such that it posits more 'real' and 'authentic' bodies and thus precludes the interrogation of staged bodies by performance practice.

13 Across his live performance practice, Fay plays on the tensions between the choreographed and the situationist, and between the aesthetics of the staged and the choreographed. In Shall we Dance (2014) (Figure 6), he stages himself as a lonely, solo dancer, offering a 'slow dance' to strangers. Whilst drawing on a social set-piece, he recounts to me at a later date this experience as opening both himself and the participants to unpredictability and intimacy. The work asks the viewer to engage with the queer body as intimate and heightens the vulnerability of the queer body in public space (to symbolic and physical violence).

14 In Something You can Feel (2012), Fay both strips back (with feminising hair removal cream) and then frantically and messily attempts to drag-up and dance as black American soul singer Millie Jackson (Figures 3 and 4). The burning smell of Imac cream on the skin and the slapdash assumption of a disco diva persona evoke an enduring and imperfectly costumed body. The performance evokes at once the excess, camp, artifice and abandon of 1970's gay club culture, yet through a burning, suffering physically enduring queer body. Made in collaboration with John Freeman, Susurros De Amor / The Whispers of Love (2015) stages an intimate homosexual encounter in a public bathroom at a club (Figure 5). It was as if, upon entering the room, I had happened 
upon two men, naked, gazing at each other by the urinal. Like a scene out of life, it was held in freeze frame for four hours, the bodies enduring their interposition on the cold, tiled floor and slowly crumpling towards each other. Berlant and Warner assert how queer cultures of sex, often occurring in public spaces, operate outside of heteronormative ideologies of sex as 'private'. They assert that such "Promiscuity is so heavily stigmatized as nonintimate that it is often called anonymous" (Berlant and Warner, 559-60). The visible sufferance and mirroring of the bodies in this performance cuts through a stereotypical view of queer sex that sees the cruising cultures evoked by the public bathroom as perversely anonymous.

Figure 3. FAY, Francis. Something You can Feel. 2012. Photograph of live performance at The Backloft, Dublin. Livestock Performance Art Platform as part of Dublin Live Art Festival.

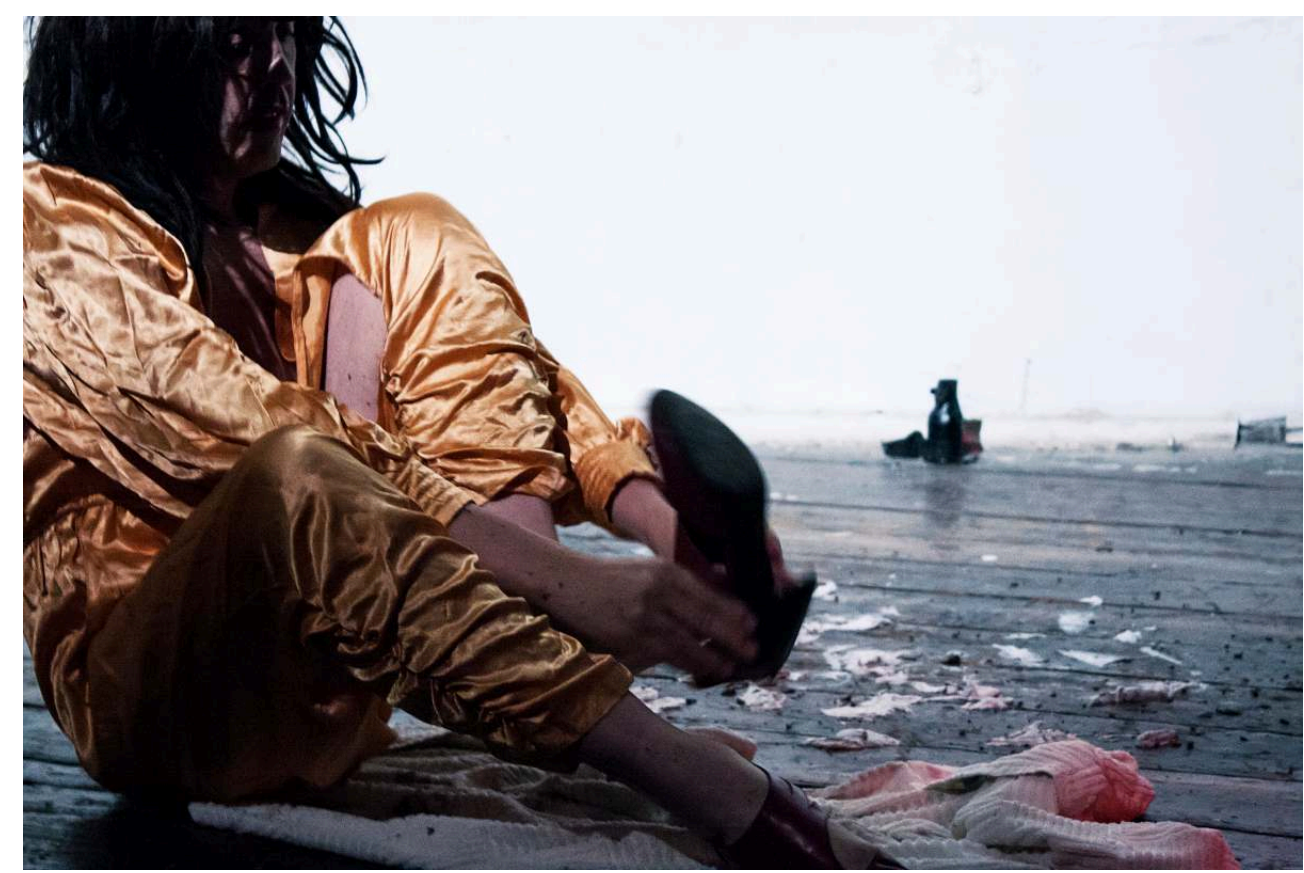

(c) http://francisfay.blogspot.com/2012/12/something-you-can-feel-ritual-dublin.html. (page accessed 26th of November 2020). Image credit: Hazel Fitzpatrick. 
Figure 4. FAY, Francis. Something You can Feel. 2012. Photograph of live performance at The Backloft, Dublin. Livestock Performance Art Platform as part of Dublin Live Art Festival.

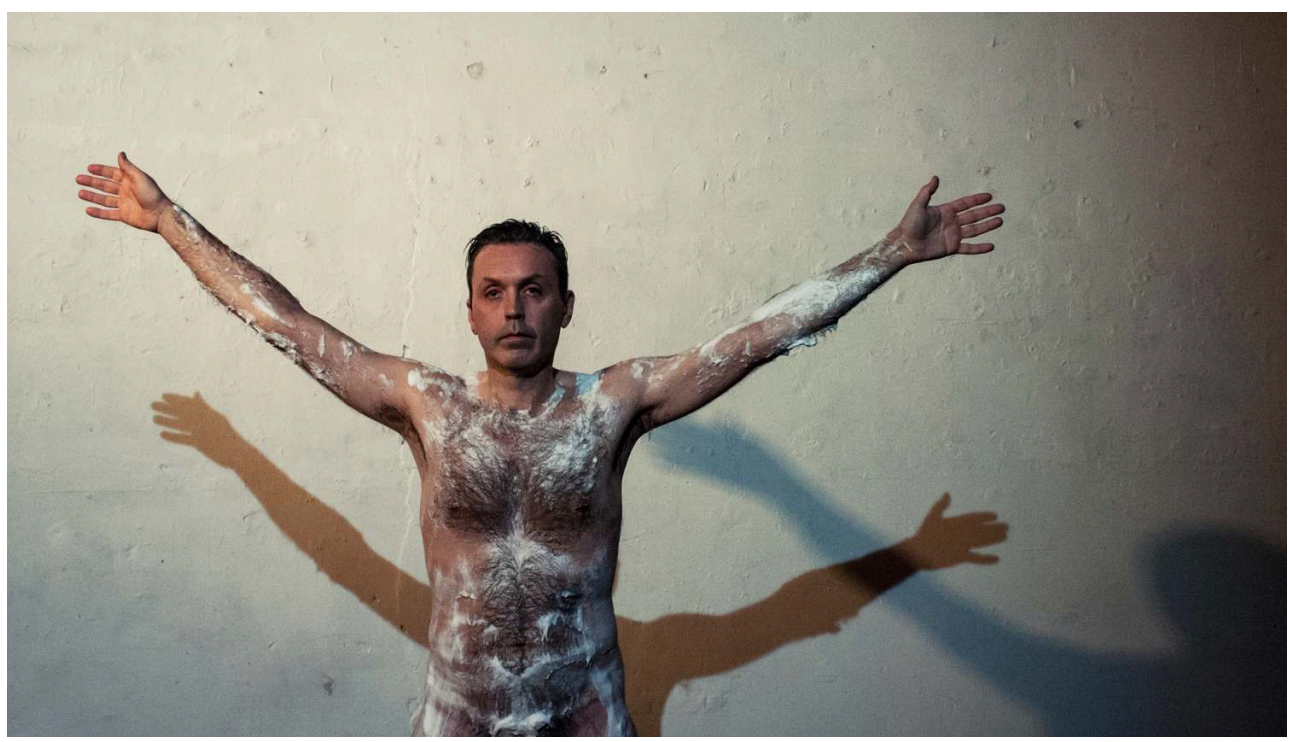

Chttp://francisfay.blogspot.com/2012/12/something-you-can-feel-ritual-dublin.html. (page accessed 26th of November 2020). Image credit: Hazel Fitzpatrick.

Figure 5. FAY, Francis, and FREEMAN, John. Susurros De Amor /The Whispers Of Love.

2015.Photograph of live Performance at The Workman's Club. As part of Live Collision International Festival, Dublin.

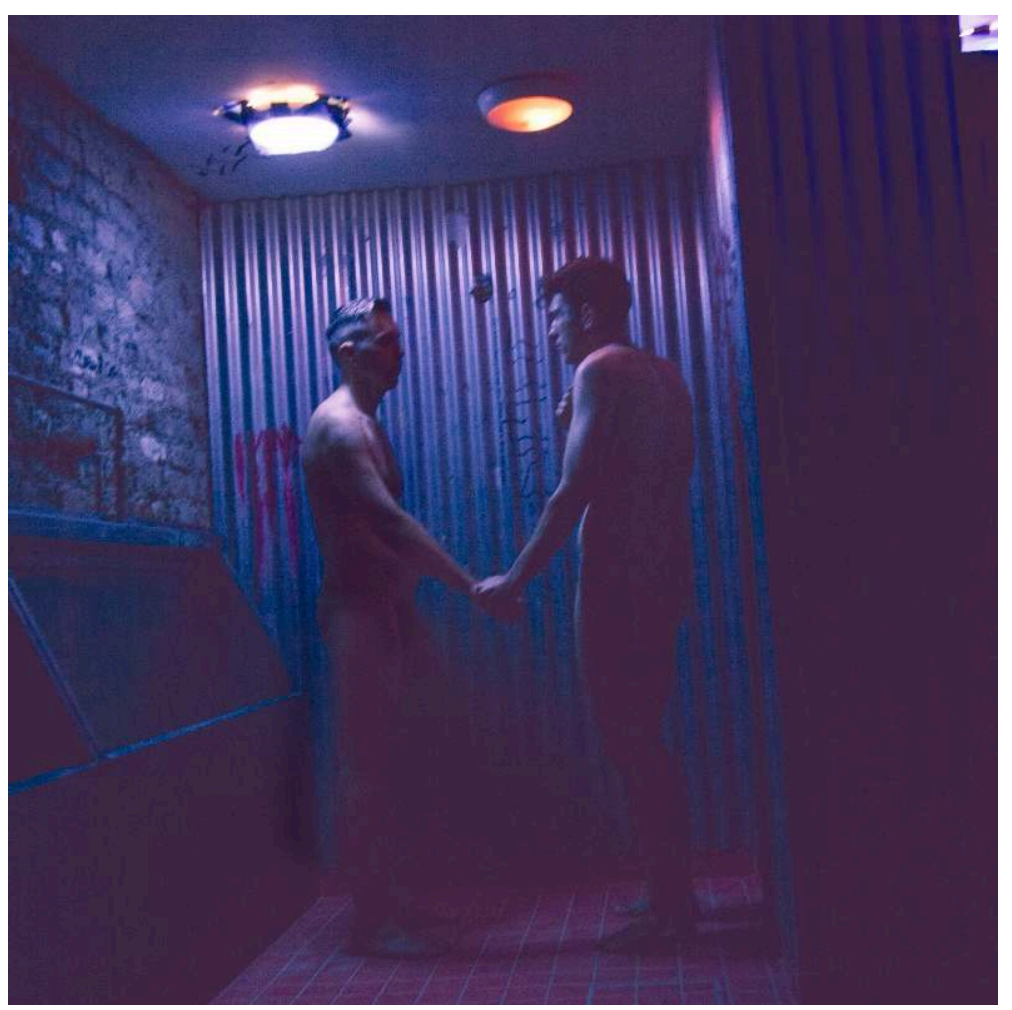

(c)https://www.francisfay.com/performances-1/amor. (page accessed 26th of November 2020). Image credit TBC.

15 I encountered both these performances live, and strongly remember the physical aftermath on Fay's body: the burning smell of Imac and how long the coldness lingered. 
These works mobilise both endurance and artifice to raise "ethical questions about how we respond to the bodies of others" (Shalson abstract); in particular, the way the queer body is stereotyped as non-intimate and less than human. Examining these performances as a set in the context of the artist's website, I read how his practice utilises endurance as a mode of performance, as well as moving between the obviously staged, the staged unfolding, and the re-staging of an apparent 'scene out of life'. In these works, the body is highly but imperfectly costumed, naked but nonetheless image-like, and through staging the performing subject becomes exposed to the precarity of inter-relational exchange. In this way the work represents the queer (white male) body as open to potential readings of explicitness and tenderness, voyeurism and empathy, artificiality and sufferance.

Figure 6. FAY, Francis. Shall we Dance. 2014. Photograph of four hour durational live performance, Temple Bar Gallery And Studios, Dublin. Still Image.

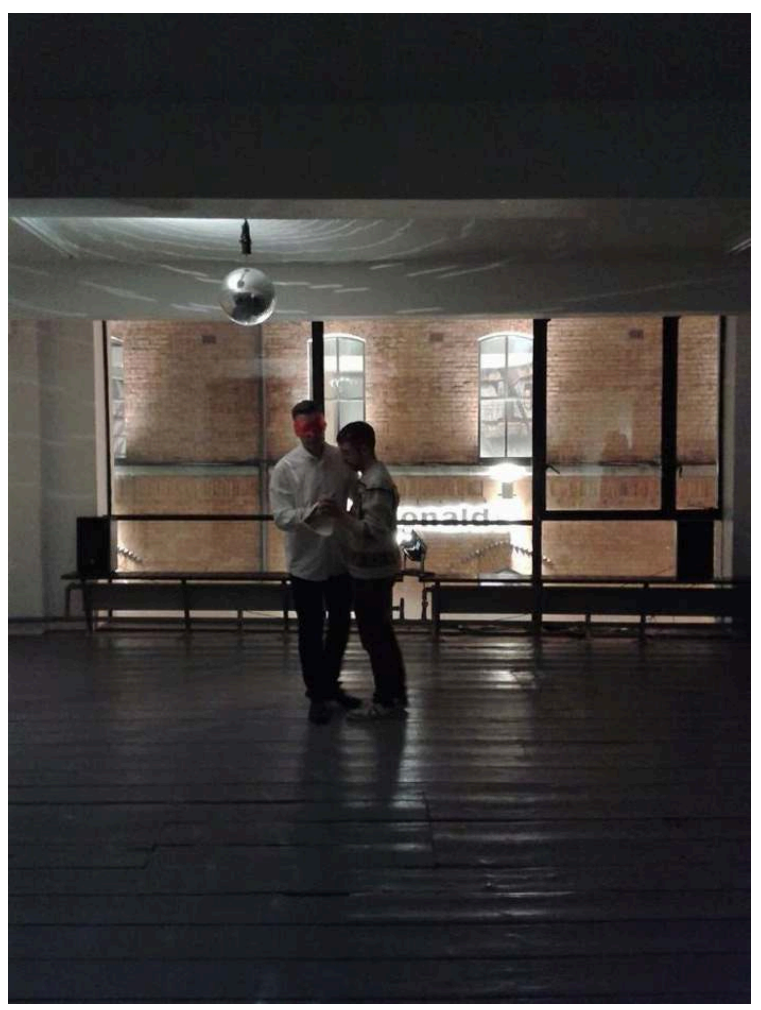

(chttps://www.francisfay.com/performances-1/shall-we-dance. (page accessed 26th of November 2020). Image credit TBC.

\section{Queering the Irish Landscape}

Jones asserts that the artifice of theatricality raises the spectre of decentred subjectivity that Western (Cartesian) discourses work hard to disavow. Theatricality, she argues, is debased in Eurocentric cultural traditions, because it is linked with women and queer, effeminised (male, white) homosexuality. She states "Antitheatricality is clearly an articulation linked to patriarchal structures of power which demand the self to be firmly identifiable in relation to the matrices of status established in heteronormative white dominated societies" (In Between Subjects 135). Thus, the artifice of theatricality can be deployed as a 'threatening queerness' that 
displaces the modernist myth of subjectivity itself as stable and coherent (In Between Subjects 20). Fay indeed further deploys artifice in his work, reclaiming it as a mark of Otherness that subjugates the homosexual subject as 'unnatural'. In his practice a marionette-like figure recurs in a bright-red wig and loin cloth, crude white mask and blocky black shoes. Bare-chested and bare-legged, this man-child is both flesh and blood body and vividly cartoonish, manifesting the queer body with a sense of both artifice and physical reality. First appearing in Beautiful Illusion (2009) performed live on a foot-high plinth, the marionette later returns in the first of a trilogy of site-specific performances to camera, Queering the Landscape (2018) (Figure 7). This nymphish figure, displaced to the karst landscape of the Burren, tap dances on the craggy rocks and drapes himself backwards across a giant boulder. A crackling, beating visceral sound, like creeping flesh, echoes across the footage as it speeds up in a backwards/ forwards motion that appears to dance the figure about, exaggerating the awkwardness of the self-display. Fay impishly orients himself in relation to the frame, emerging in close-up from below, jumping out playfully from behind the boulder, or retreating in jerky sped-up movements. He uses a number of physical and digital devices to play with significations of the body, pushing and pulling it between vividly artificial, and breathing, beating, flesh and blood. The body is visceral and machinic, fleshy and fake, man and mirage. In this way, Fay both summons and complicates the artifice of the queer and the digital body.

Figure 7. FAY, Francis. Queering the Landscape. 2018. Photograph, as part of video performance to camera.

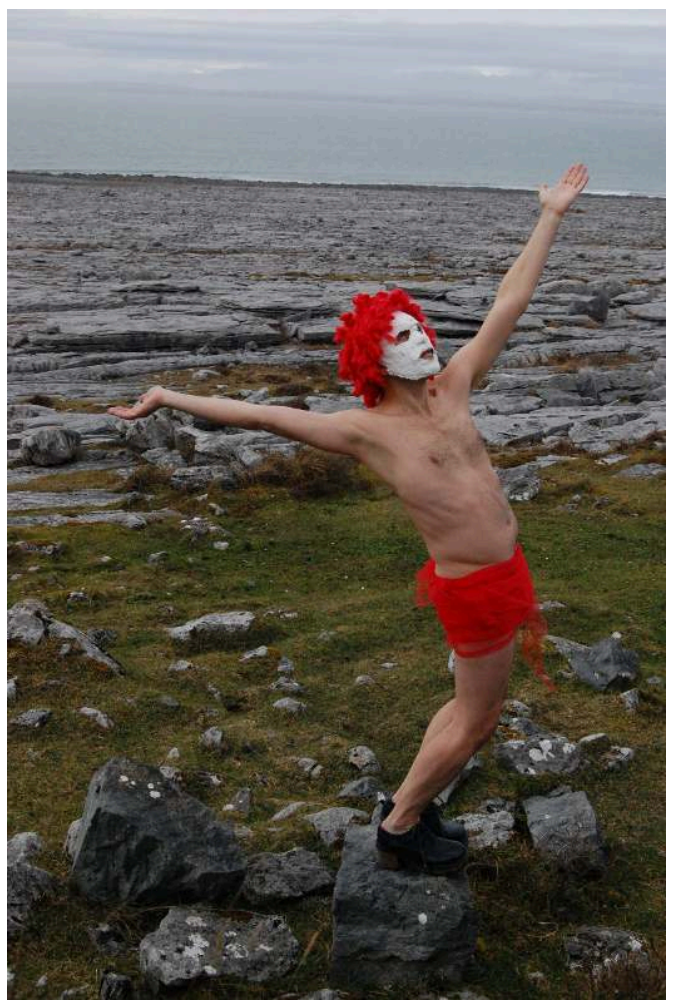

(Chttps://www.francisfay.com/performances-1/queering (page accessed 26th of November 2020). Image credit: Katherine Nolan.

17 The karst landscape of the Burren is both iconic and yet unlike the emerald green of idealised Irish imagery. Situating this cartoonish, awkward character in the landscape 
is incongruous, and yet there is a kind of kinship of the 'alien' with this moon-like, otherworldly place. Just as the concept of kinship, which in many indigenous cultures (Aboriginal, Native American, Mayan, Inuit) enables "non-human material kinships" that produce a "relational existence to the world", the land itself is conceived as queer (Harris, 215-218). Some Irish Studies scholars have argued for "the queerness of Ireland herself", as under British colonisation its definition "as a 'queer nation' was appropriate because of the fact that her status as a colonial 'other' rendered her perpetually outside the realms of the normative imperial centre" (Price 222). Whilst this offers a queer reading of history, this concept of Irishness as an oppressed Other persists also in nationalist heteronormative narratives of identity. Aidan Beatty traces an Irish postcolonial masculinity borne in the Irish Nationalist movement (1884-1938) in which "national power was conceived of as male potency, and the recovery of one would supposedly parallel the recovery of the other" (Beatty 1 ). Thus, the recovery of male power, was inextricably linked to the power of the nation. This conceptualisation arose in the struggle for Irish independence and later became the dominant national narrative in which sovereign nationhood was produced through a heterosexualist logic of masculine power and dominance over a submissive femininity (Beatty 1). Fay skilfully redeploys the land to conjure a queer Irishness, performing himself as both in and out of place in its iconic landscape.

Figure 8. FAY, Francis. Bog Body. 2018. Screenshot, Instagram post of video performance to camera. Screened as part of Diffraction, Performance Video Art Event at 126 Gallery, Galway.

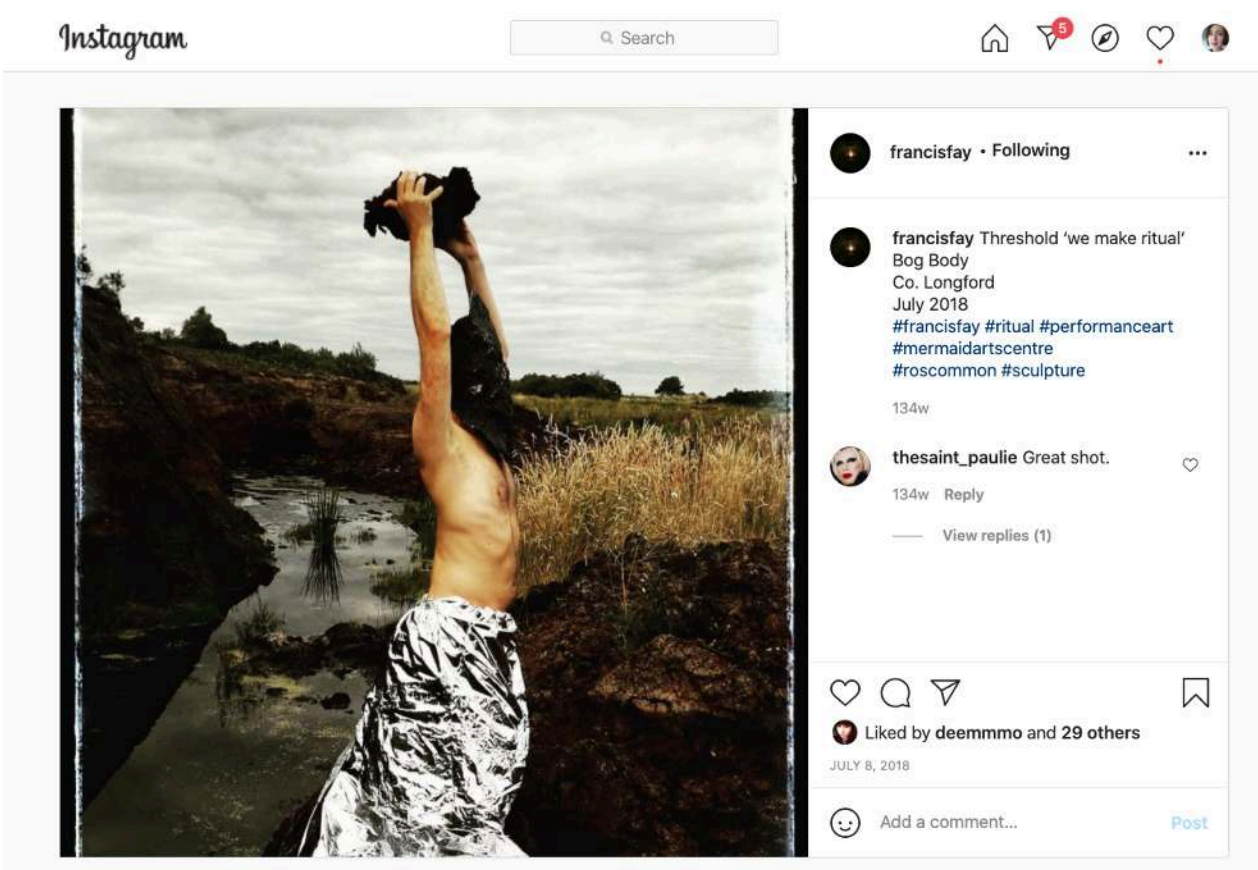

(Chttps://www.instagram.com/p/BmO0cfRn100uSAyQYJUjbRwuGgnscJ22WG2Yso0/ (page accessed 26th of November 2020).

Beatty asserts that Irish normative masculine identity was naturalised as being rooted in a Gaelic pre-history and the earthy agricultural landscape and soil of Ireland (13). Offering the viewer a sod of turf through the camera in Bog Body (2018), Fay dons a foil cape that shimmers against a sedimented, earthy peat landscape (Figure 8). The head of this man-creature is itself apparently made of peat: this is a body both of the bog, 
and alien to it. He queers the masculinised, earthy Irish identities born in the lives of working people as the colonised class, and national over-identification with the turf of the land. Placing this queer deity in the landscape disrupts the anchoring of concepts of land and nation in the heterosexual concept of the family in Irish national narratives and identities. Fay's use of juxtaposed signifiers of celebratory artifice and earthy, prolific naturalness produces a queer futurity. The body moves with a ritualised staccato quality, controlled by the backwards/forwards motion and jump cuts of the footage. The strange temporalities of this past/present future disrupts the historical time of Irish nationality, compressing and stretching it to follow alternative cadences and trajectories. Through an imagined queer Irish mythology the work disrupts the time of reproduction and generational inheritance and uproots the naturalised "historical past of the nation" that "glances ahead to connect the family to the future of both familial and national stability" (Halberstam In a Queer Time and Place 5). In Threshold (2018) Fay naked in a forest, encounters a sequined gold shift dress and descends into a lake to emerge transformed, as a glinting, luminous, camp sun-god walking towards the camera (Figure 9). Again, the motion and time of the video are out of sync and it is ambiguous whether the body is being danced or made superhuman by the artificial digital movements. These digital effects are part of a strategy of costume and staging as transformative, positioning the gay subject as sacred through their difference. This aligns the artifice of queer with that of the digital in a past-present futurism, and as if superseding Irish Catholicism with a new shimmering camp spirituality, imagines a digital utopic Ireland.

Figure 9. FAY, Francis. Threshold. 2018. Screenshot, Instagram post of video performance to camera. Screened as part of Diffraction, Performance Video Art Event at 126 Gallery, Galway.

Instagram

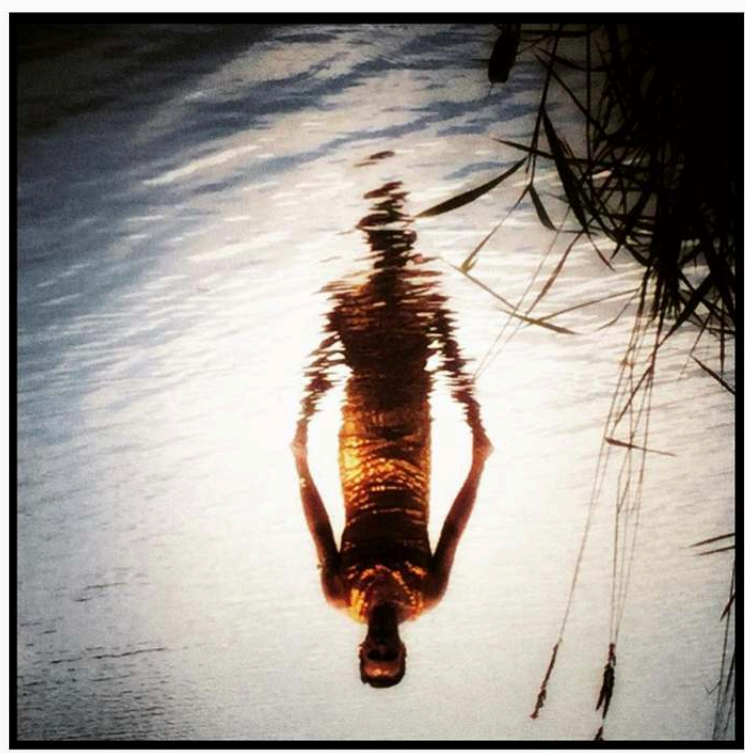

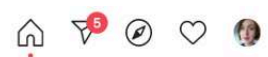

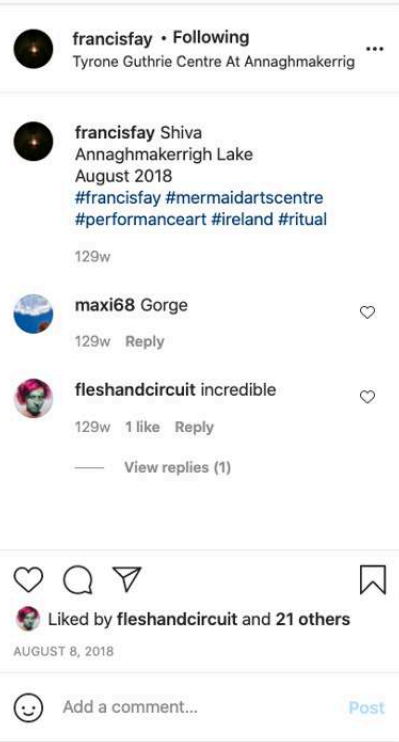

Chttps://www.instagram.com/p/Bk_GOkGHdU6SFpThbyctiFMiy6qjZSsRSBM3Sc0/ (page accessed 26th of November 2020).

Fay 'queers' the Irish and digital landscape, a bold act of reclamation deploying the celebratory artifice and strategic irony and 'outness' of camp. 'Queering', according to Ahmed is a decolonising act, that involves the deliberate act of misuse, which makes 
odd, perverse, atypical and out of place (197-229). He performs himself as out of place, and across his practice deploys an identification with this Otherness to draw attention to broader, intersectional issues of power, privilege and difference. I encountered Social Distancing (2020), a response to the conditions created by the COVID-19 pandemic, during its on-line release in September 2020 (Figure 10). Filmed in the Victorian flower gardens in Dublin, in an odd, garish moment, the red-wigged marionette momentarily occupies a large, empty marble plinth and then disappears. Recast as the fool, sanctioned to speak truth to power, the marionette occupies the space where a statue of the British Viceroy to Ireland once stood. Fay draws attention to the historical 'gap' through an incongruous queer body, linking seemingly disparate discourses: protests against statues of dominant actors in the Anglo-European slave trade, the inequalities of class and race exacerbated by the pandemic, and the simplification of Irish Identities as colonised and oppressed, and therefore somehow outside of such debates. Fintan Walsh asserts that despite the Irish History of forced migration due to poverty and famine "a deep-seated structural racism has informed Ireland's response to immigrants", quoting the direct provision system in which asylum seekers are held in a state of 'non-citizenship' for three to seven years (11). Fay's striking use of selfothering draws attention to both Irish identity as the oppressed Other and how this narrative itself masks acts of Othering and oppression.

Figure 10. FAY, Francis. Social Distancing (2020). Video still of performance to camera. Screened as part of Mirco Moments, online event (Facebook. Instagram, Twitter, YouTube and https:// ciacla.com/online-program/), Contemporary Irish Art Centre Los Angeles.

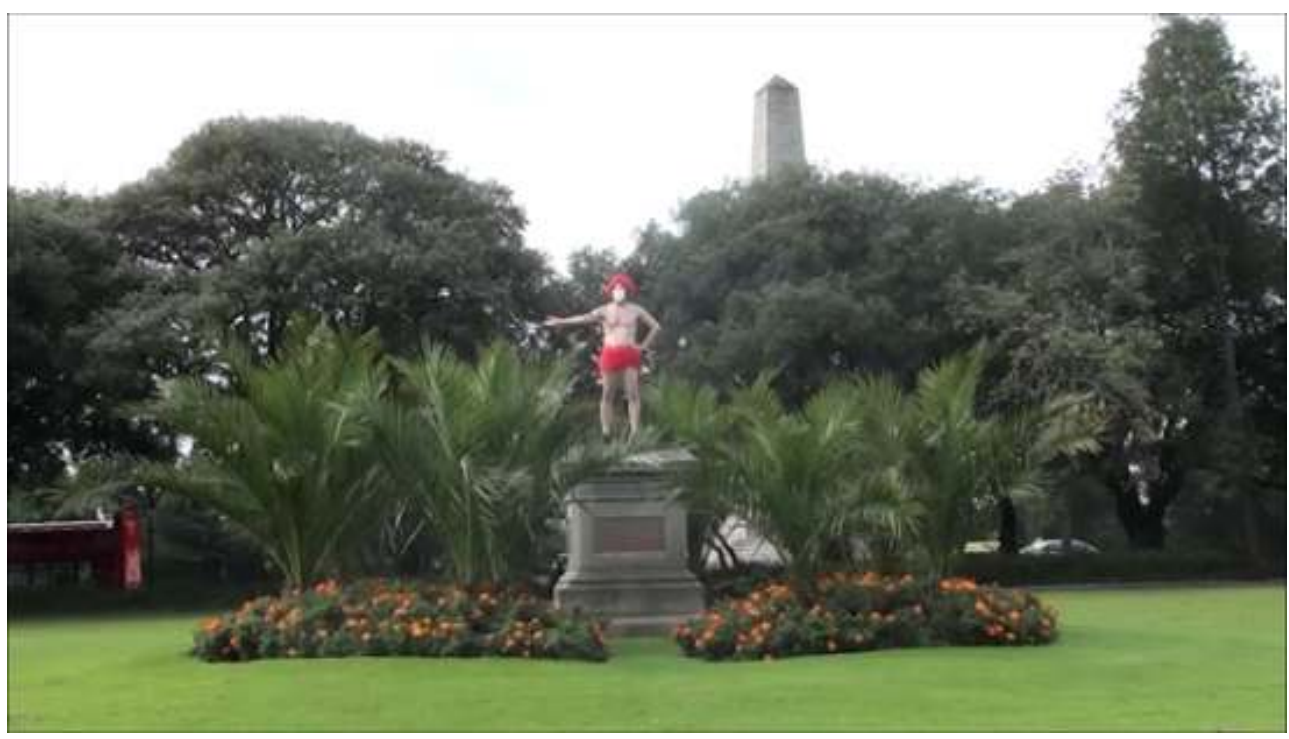

Chttps://www.francisfay.com/performances-1/https/vimeocom/454889902 (page accessed 26th of November 2020). Image credit: TBC.

In Knight of Mirrors (2015) he activates the site of Grangegorman, formerly Saint Brendan's mental health institution (est.1810) in north inner-city Dublin (Figure 11). He slowly parades the grounds as the othered 'insane' dressed in an institutionalised white straight jacket. In the place of a face is a mirror, signifying those obscured and dehumanised by the institution, and its reflective surface always holding the threat of seeing the self as Other. Fay's radical, empathetic occupation of those outcast and marginalised by society invites the viewer to see themselves in his Otherness. In this way, he strategically mobilises queer Otherness as an identification with and drawing 
attention to, a range of forms of oppression, from race to the stigma of mental health, a politics that is playfully and provocatively performed across his practice.

Figure 11. FAY, Francis. Knight of Mirrors. 2015. Photograph of live performance, Grangegorman Dublin. As part of Dublin Live Art Festival (Winter).

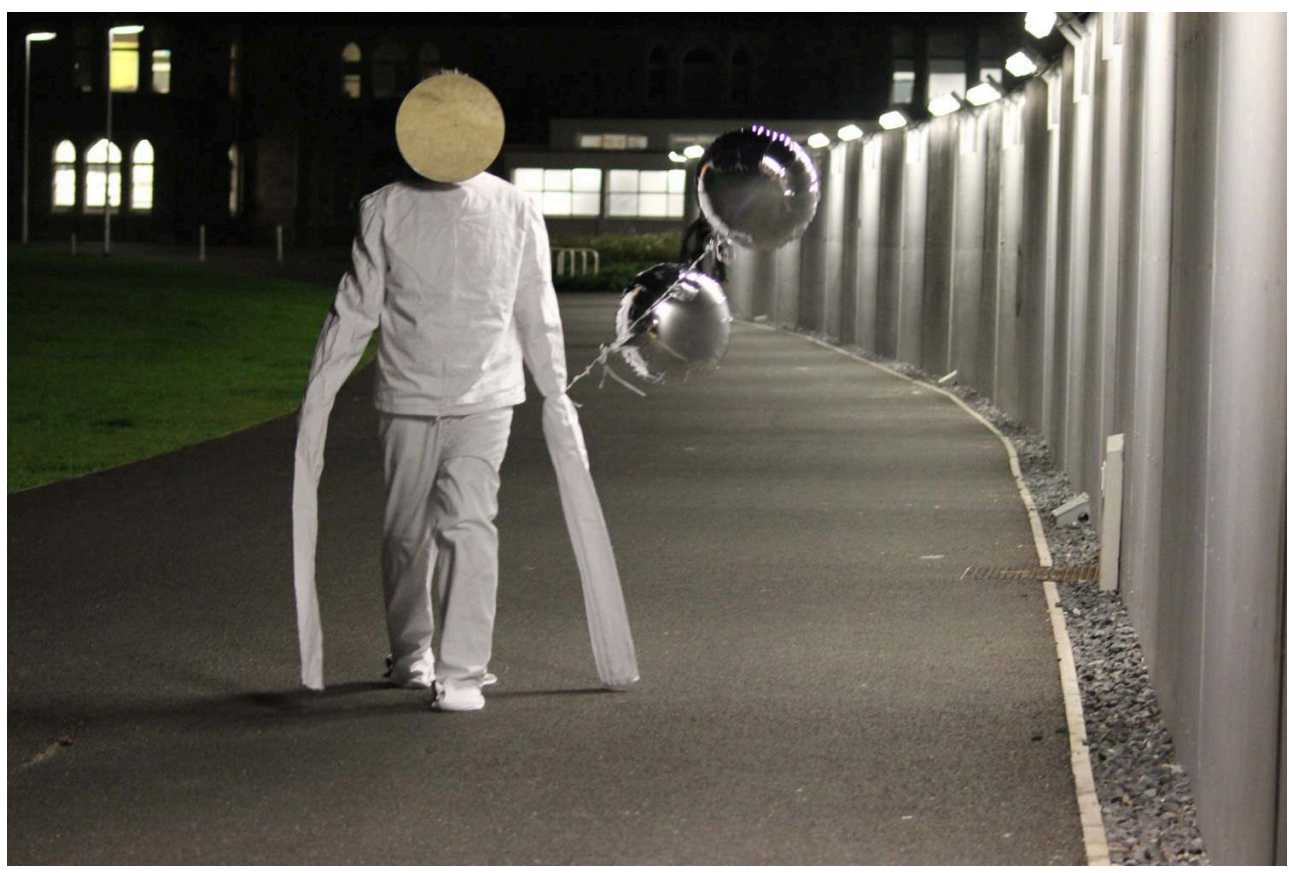

Chttps://www.francisfay.com/performances-1/project-three-hsctr (page accessed 26th of November 2020). Image credit: TBC

Employing Instagram as an on-going feed of social documentary as well as 'sketchbook' for experimental self-portraits, Fay mobilises the social media profile to visibly map the (queer) self within physical and digital contexts. That is, as relationally mapped to Others, as well as cultural objects and iconic spaces. This visualises both a geohistorically situated and a fantastical self, grounded, yet dispersed, in a plane of digital effects. Within the frame of the social media profile, these images produce a subject who is impacted and shaped by Irish cultural tropes, contexts and their associated historical discourses: that is by their situation in a post-Catholic, post-colonial Dublin. In contexts such as the Victorian flower gardens, St. Brendan's mental health institution, the Burren, the bog, the public toilet and the 1970/80s club, Fay represents himself as spoken by and speaking to these sites, drawing out their cultural significance and the shaping of the subject through the histories they provoke. He presses upon these contexts, queering significations: through digitally layering they become his drag. There is both a veiling and unveiling, claiming cultural symbols as queer masquerade and making hidden lived experiences visible.

The practice evokes a subject both concretely in place, and yet out of place, refusing a fixed sense of belonging or exclusionary tribalism. The body - gawdy, artificial and othered from the Irish landscape - strategically mobilises the Otherness of queer subjectivity to claim public space and imagine a queer Irish futurity. The artifice is evoked through the material and the digital, through which the body is both danced and yet sacred: the digital performs the body and through this the digital effect itself becomes queer, evoking the "strange temporalities" of queer time (Halberstam 1). That 
is not to claim that these works somehow overturn the pervasive exploitation of digital capitalism, but that they can be read as interventions that provocatively deploy otherness, in and through the digital platform. As an Irish queer subject, continually and relationally shaped by his context, Fay is always already negotiating oppression through recuperative, embodied critical strategies in order to reclaim agency.

\section{Magee's Chronic Pleasure-Pain}

Day Magee, also an Irish artist, has a similarly fluid approach to performance across live and digital contexts. Magee too plays on and in the Instagram profile as format, mobilising this frame to speak to and about their genderqueer identity, that is as identifying beyond or outside of the binaries of the gendered identities of masculine and feminine (Thorne, Kam-Tuck Yip, Bouman, Marshall and Arcelus). Fay's artistic strategies of queer as othered, camp, out-of-placeness contrasts with Magee's deployment of gender ambiguity, and whilst both utilise the significations of social media as personal profile, the confessional nature of Magee's performance practice mobilises this differently.

Figure 12. MAGEE, Day. Do It To Me. 2016. Instagram post of live performance at MART Gallery and Studios Dublin. Accessed via Instagram post $16^{\text {th }}$ September 2016. Caption: antichrist supertwink eleganza for tonight's performance of Do It To Me as a part of Livestock in MART for \#culturenight.

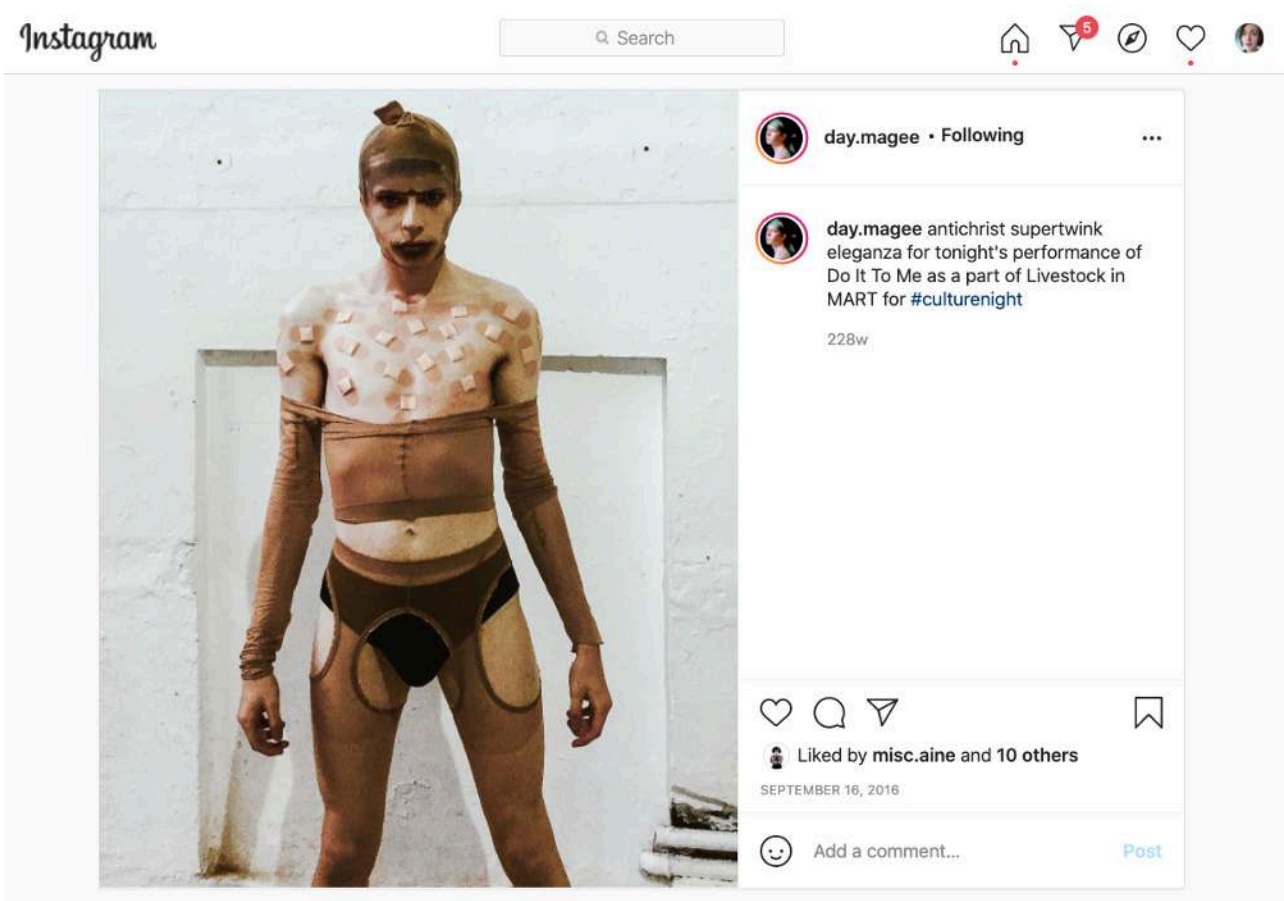

(c) https://www.instagram.com/p/BKbJkIRgqkD/ (page accessed 26th of November 2020)

My first encounter with Magee's work was in the context of experimental performance platform Livestock, at the time curated by Fay and Eleanor Lawler. Performing Do It To Me live at MART gallery 2016, they were poised on all fours, wearing scant BDSM attire improvised from tights, gimp ball in mouth (Figure 12). They thrust their hips towards a mirror on the ground in time to a haunting, thumping track in which they narrate a sexualised fantasy, requesting: "make me bleed like a real girl". As I redescribe it here, 
there is a discomforting sexualised violence unavoidably apparent in the work. Yet in the "frenzied present" of the live moment this was subsumed in the embodied, social experience and club-like aesthetic. Here the viral ontology of performance, reveals itself in these conflicting subjective readings of the performance experienced as live and as artwork revisited. I seek to untangle the contradiction of these two readings in this analysis. Figure 12: MAGEE, Day. Do It To Me. 2016. Instagram post of live performance at MART Gallery and Studios Dublin. Accessed via Instagram post $16^{\text {th }}$ September 2016. Caption: antichrist supertwink eleganza for tonight's performance of Do It To Me as a part of Livestock in MART for \#culturenight.

Figure 13. MAGEE, Day. Mission Statement. 2020. Video still of performance to camera, digital video.

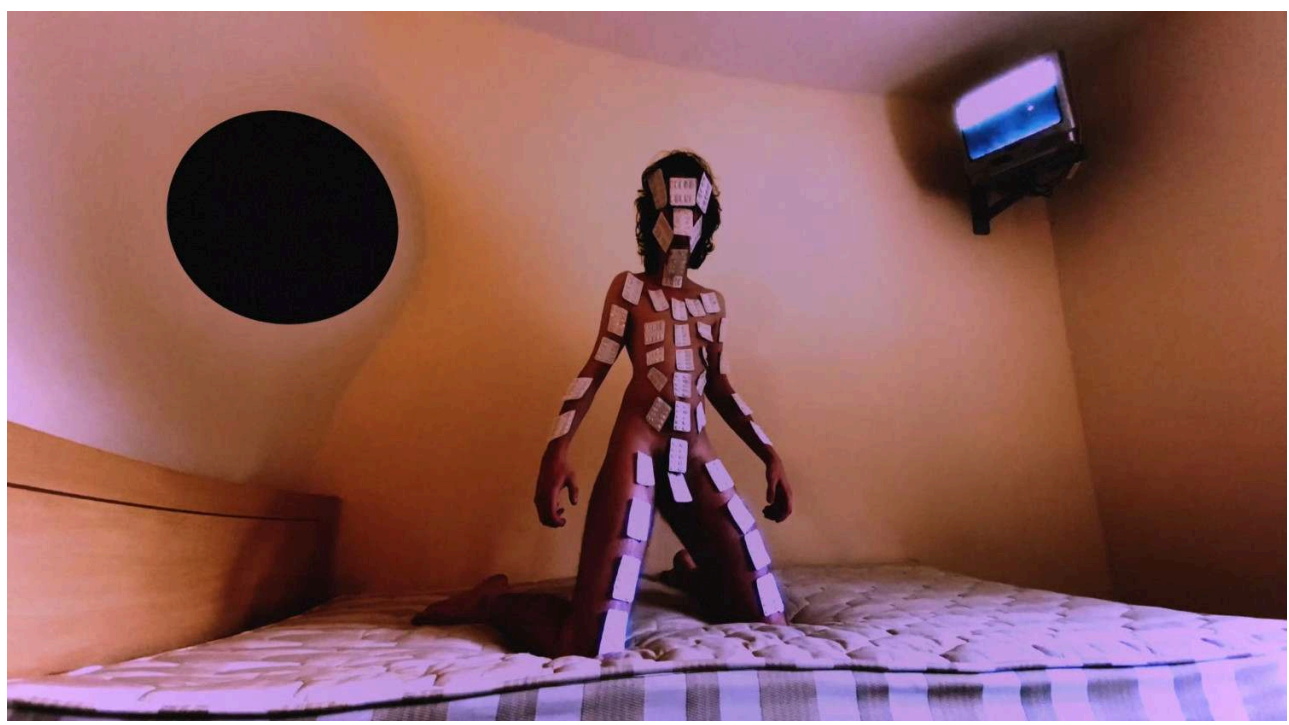

(c) https://www.youtube.com/watch?v=wKPsSVQ78-U. (page accessed 20th of November 2020)

Magee's body movements were charismatic, mesmerising, and yet there was vulnerability in the work, their body, slender, pale and delicate. Viscerally representing their inner emotional life spoke of a desire to comprehend the self. I later learn, as I encounter works in my social media feeds, that their practice is concerned with their chronic pain, reframing my understanding of the work as a way of managing this condition. The video work Mission Statement (2020) brings me into their experience of living with pain (Figure 13). A warping super-wide-angle shows a figure standing on a bare mattress, naked, but for lines of opioid pill packets across the limbs, torso, face and pubic hair. A TV flickers in the corner as an echoing voice narrates the suffering they endure daily. The "dull spur and iron thrust into the white hot black" of chronic pain, opens as a dense black void in a mundane magnolia wall. The work evokes the grating of everyday existence through ever-present pain. There is "no self without mediation" points both to the double bind of existing on a plane of medication or pain, and to a subject that can only know itself through these conditions. It also points to the use of mediated re-enactments of the self as necessary copying mechanism.

This use of performance as a means to visualise on-going suffering, can be seen in practices such as those of Bob Flanagan and Martin O'Brien. Both of these artists employ performance art as a way to understand and manage their lived experiences of the chronic illness, cystic fibrosis. In works such as Mucus Factory (2011) O'Brien focuses 
on the medical routine that he is forced to submit his body to in order to prolong his life, re-performing these repetitious acts and utilising the mucus they produce as 'material'. He performs the medicalised, abject, sick body that suffers its own maintenance, and through the re-framing of this regime as art practice seeks to reclaim agency from within this relentlessness (O'Brien). Flanagan utilised sado-masochistic practices, the most famous of which involved Flanagan nailing his penis to a wooden board in Nailed (1989) (Sandahl). Such deliberate self-violence was employed as a means to sublimate his suffering through its ritualization as pleasure-pain. Magee's work chimes with these approaches in its utilisation of performance as a way to reclaim the sick and suffering body, and even more specifically with the sadomasochistic tone of Flanagan's practice.

While Magee's work draws on BDSM (bondage, discipline, sadism, masochism) cultures, it does not utilise the body's endurance as a mode of performance. O'Dell discusses early performance works that test the physical and psychological limits of the body, such as Ulay/Abramovic's Talking about Similarity (1976) in which Ulay sews his lips together with a needle. She asserts that in such work a "masochistic bond" develops between the performer of such acts and the audience who witness their pain (xii). Such works push the body to 'confess', that is to make sufferance visible. Indeed, this impulse is present in Magee's work. The pain that they chronically suffer is a physical manifestation of the embodied trauma of conversion therapy and sexual assault: religiously motivated persecution for their gender (daymagee.com). Caruth describes trauma as an event so overwhelming that it is "not assimilated or experienced fully at the time, but only belatedly, in its repeated possession of the one who experiences it." (4). It is characterised by both its absence and its continual repetition, as is manifested in post-traumatic stress disorder in which traumatic scenes constantly replay themselves in the mind of the victim. In this way, "To be traumatised is precisely to be possessed by an image or event" (4-5). Through these concepts Magee's work can be understood as an attempt to re-tell, make visible or exorcise trauma through reperformance and self-imaging. The phrase "make me bleed like a real girl" takes on new meaning, as both a desire for one's pain to been seen and a re-performance of the original violence on the body.

Similar to Flanagan's re-infliction of pain as a means of reclaiming the agency of the sick body, Magee's practice, when read through their experiences of gender persecution, becomes a means to reframe and reclaim embodied experiences of pain and shame. Yet, these are not the raw masochistic, body puncturing acts of Flannigan or Ulay/Abramovic. They are rather an attempt to testify to the recurring pain of trauma through its narrativization and stylisation. Magee's experience of pain is channelled into embodied re-enactments, their stylised movements in response to the soundtrack of their own self-narration. This is particularly striking in live works, where they mime their own mediated words, re-narrativizing and re-telling the self to the self: an uncanny and disjointing mediation.

Pain is thus aestheticized in the work. Through the comparison of these practices the question arises as to whether this aestheticized pain is somehow less raw and real than the machoistic endurance art practices. The recurring visualisation of pain as a black void in Mission Statement offers a useful example. I read this as a recurring motif across their Instagram profile in both formal works and informal experiments such as those made when they are bed bound with pain. The void invades and opens the body as 
wound, making visible how chronic pain feels like it pushes their flesh apart. Jones asserts "the wound [...] makes the body of the other available as meaningful through identification. It makes pain readable as inscribed in and on the body" (Performing the Wounded Body 50).

The wound in Magee's work is a digital effect, its black flat opacity contrasted against the fleshy body and the photographic grain. Discussing the self-wounding BDSM work of Ron Athey, Jones argues that the aestheticization of the wound and acts of wounding (via the photographic documentation of performance) rather than being less authentic than the experience of live works, can make the pain of another more apprehendable, by allowing enough distance to empathise with pain that may otherwise be too overwhelming (Performing the Wounded Body 49). There is also the question of pain that is not consumable as spectacle: is it somehow less real or less valued than pain that is visible? Pain that cannot be traced to a biological cause is devalued in Western discourse, producing an impulse to seek its visibility. Some pain can only be known through its re-representation.

In Magee's digital drawings this wound becomes orifice: a site of pleasurable penetration. Shifting between piercing chronic pain and site of pleasurable penetration, this hole signifies that suffering in their work is sexualised, as the embodied trauma of gender persecution. The black hole is counter matched in the work with penetrating symbols - 'drill' or 'screw' or 'horn'. In Baconesque drawings masculine figures wrestle, entangled with visceral tubes that are both inside and outside the body: both penetrating and penetrable. This ambiguity points not only to the embodied experiences of a genderqueer subject who "identifies with neither, both, or a combination of male and female genders", but also to the binding of pleasure to pain (lexico.com). Thus Magee uses the iconography of BDSM cultures to open up the kind of 'queer space' in which simula asserts, subjects can transgress and resist heteronormative gender regulation (71). Their practice is a space in which the entanglement of pleasure, pain, and gender are fearlessly wrought in their complexity and contradiction. In this way the work calls attention to the fact that '"gender', as it is lived, embodied, experienced, performed, and encountered, is more complex and varied than can be accounted for by the currently dominant binary sex/gender ideology of Eurocentric modernity." (Stryker 3).

\section{Confessional Art and the Age of Social Media}


Figure 14. MAGEE, Day. and I let it happen anyway. 2020. Instagram post of performance to camera, Instagram Post $7^{\text {th }}$ of April 2020. Caption: "and I let it happen anyway" [from the "unfinished projects" archive].

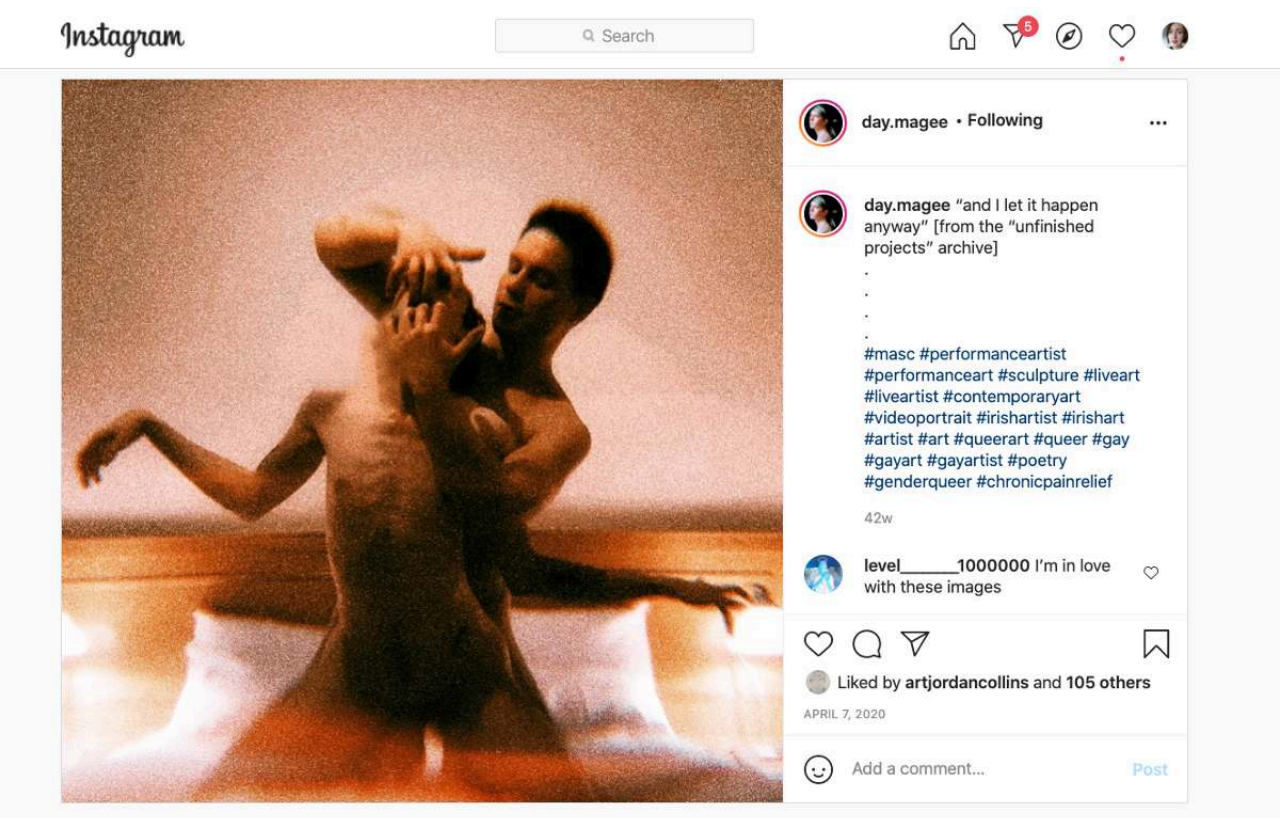

Chttps://www.instagram.com/p/B-rKdjRHaNp/ (page accessed 20 th of November 2020).

There is an explicitness in the work, both sexually and emotionally. In and I let it happen anyway [sic] (2020), naked male bodies wrestle on a bed (Figure 14). Magee's mouth is being prised open, their arms spread in graceful submission. It is an ambiguous image of a violent sensuality, in a shaded intimate bedroom. References to Sophie Calle's encounters with strangers in The Hotel, Room 47 (1981) come to mind: the tangle of bedclothes, and simultaneous intimacy and conspicuous anonymity. There are resonances too with the confessional in the work of Tracey Emin in which she recounts lived experiences of rape and abortion and their subsequent manifestation as emotional turmoil in her life (Fanthome). Magee's practice has strong parallels in the unshrinkingly explicit, emotionally entangled autobiographic as a response to sexualised trauma that continues to replay itself as self-destruction. Whilst now part of the cannon of contemporary art, Emin's work has often been viewed as problematic. Fanthome discusses how it can position the spectator as either voyeur or sympathiser (32). Such sexual and emotional explicitness can be read as fearless or attentionseeking, cathartic healing of trauma or over-disclosure. Magee's work too takes the risk of being read as too emotional, too explicit and too personal to be of critical value, and thus mobilises the tension of this problematic, in order to account for aspects of lived experience that may be complex and contradictory.

Furthermore, it might be asked, what does this kind of explicit, confessional work come to mean when it is read in the context of social media? Lambert asserts how pain, intimacy and secrets have become cultural currency in these contexts and motivate users into acts of disclosure in public forums (Lambert). This is instrumentalised in digital economies, as epitomised by the use of Instagram by the Kardashian brand as a 'tell all' form of marketing. Thus, the social media context complicates this confessional mode of art practice even further, bringing the risk of dehumanisation, and conflation with such commercialised forms. Yet it is this exploitation of intimacy that makes these 
contexts such complex and urgent territory for critical intervention. Magee redeploys the nature of the Instagram profile account as autobiographical frame, converging images of disparate public/private selves. Across their feed I read documentation of live performances and formal portraits of the artist, images of them alone in bed bearing chronic pain and homoerotic drawings of masculinised bodies tussling, alongside images of their father's illness and their intimate last moments together (Figure 15). Through this co-mingling of selves, personal and professional, public and private, so symptomatic of digital and social media, Magee unshrinkingly mobilises the disclosure that this context elicits. Read through their desire for pain to be made visible and for the transformative power of being witnessed by others, their use of networked digital media instantiates human connection. The work is of course open to other objectifying and even gender-phobic interpretations in the social but disinhibited context of on-line media. O'Riordan asserts that whilst digital cultures have offered affordances of queer futurity and new gender terms, they have also fostered new forms of homophobia (192-195). However, Magee's works on grief further underwrite the potential for identification through this explication of pain.

Figure 15. Screenshot of Images with Father. MAGEE, Day. [@day.magee.] n.d. Instagram Profile.
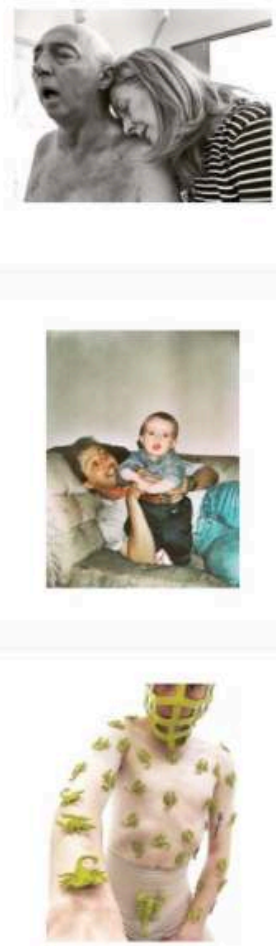
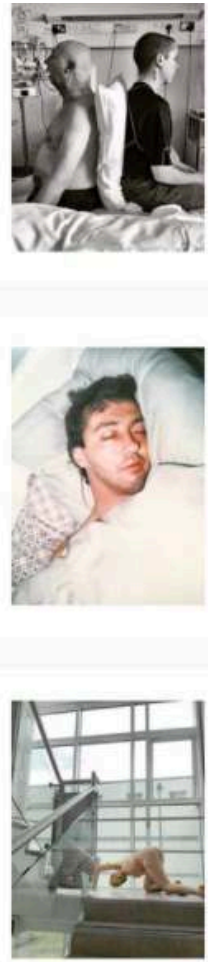
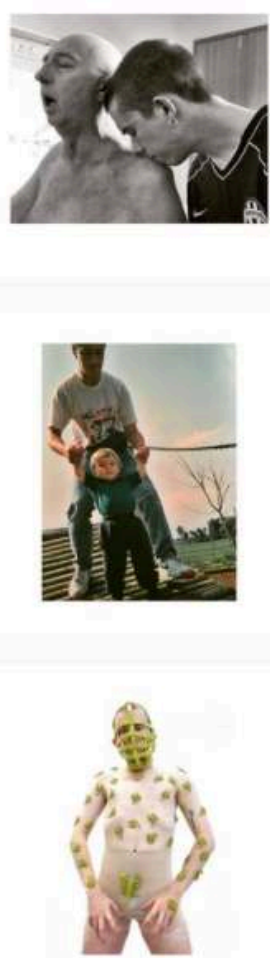
Figure 16. MAGEE, Day. Garden Keening Door. 2018. Photograph of live performance, Tulca Festival, Galway.

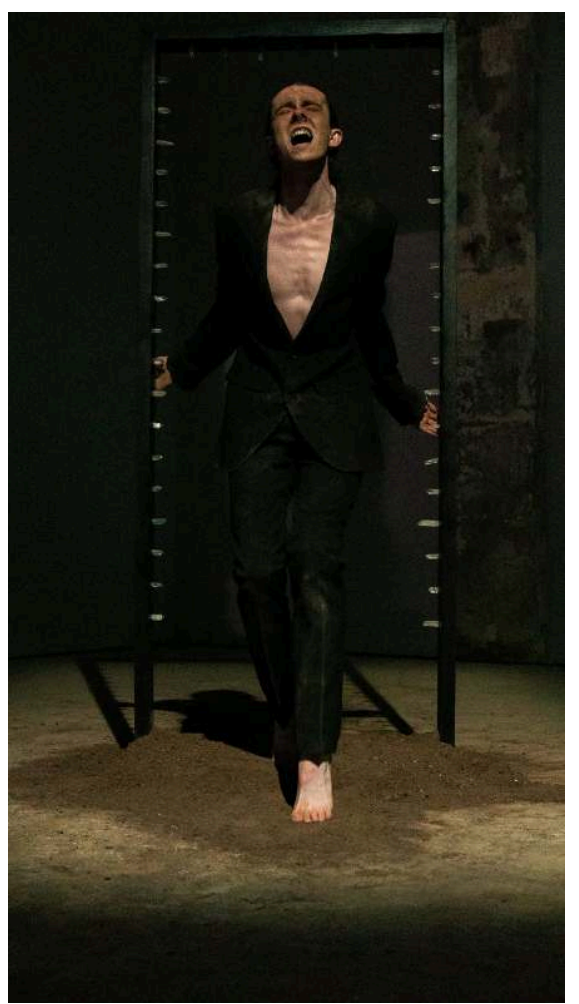

Chttps://www.youtube.com/watch?v=a_dlk6dwSWU\&feature=emb_logo (page accessed $20^{\text {th }}$ of November 2020). Image Credit: Jonathan Sammons.

This is striking in a series of performance works and posts grieving their father, with characteristic emotional rawness. Garden Keening Door (2018), performed live as part of Tulca Festival Galway, I experienced first as Instagram image and later as hand-held documentation on YouTube (Figure 16). Much live performance, I argue, is dominantly received in this way: as raw documentation posted 'off the cuff' on social media. A black frame, like a doorway without a door, stands in a large gallery space. It is surrounded with a pool of soil and an audience has gathered. Blades stud the inside, marking the pain of passing through. It is a resonating, flickering threshold between life and death, as well as Magee's own passage through grief. Howling, hauntingly they incant a version of the Irish keener, a woman whose role was to wail as part of traditional death ceremonies, a catharsis of grief through its communal representation. Magee's voice echoes between choral singing and deathly, guttural yelps and cries that swell forcefully as they finally pass through the deathly frame. They manifest grief as an intensely in-between mode of existence in which one lives with the spectre of one's own death as well as with a connectedness to the social body of those before, now and after. This work reframes my understanding of the practice from the discomforting sexualised violence encountered previously: flipping and claiming the gendered concept of the keener, they become one who communes, through publicly bearing grief on behalf of others. 


\section{Trans*medial Genderqueerness}

Social media is widely understood as sites of identity performance (Terras, Ramsey and Boyle 131-132) - not simply through offering self-publishing tools but rather a social field that relationally performs identity, thereby raising questions about how subjectivities are performed within and by a transmedial mix of user content and music, celebrity cultures, entertainment, news, propaganda and new forms of edutainment, infotainment and influencer culture. It calls to mind a Baudrillardian dystopian postmodern subject "caught up in a play of images, spectacles and simulacra" in a "carnival of mirrors" (Kellner n.p.). The rise of 'playbour', that works to harness the labour of the prosumer through an ideology of play has enabled the hyperaccelerated production and consumption of the (still/moving) image (Chatfield 106). In the resultant pervasive condition of "living under the image," Harbison argues that we are continually performed by images as they "pass through the body" (Harbison 15-16). The codes of the body that we consume and perform as images on an on-going basis encode the language of the lived body, seeping into our flesh through repetition.

Figure 17. Image with Greenhead scarf and other image, screenshot of Instagram profile. MAGEE, Day. [@day.magee.] n.d. Instagram Profile.

Instagram
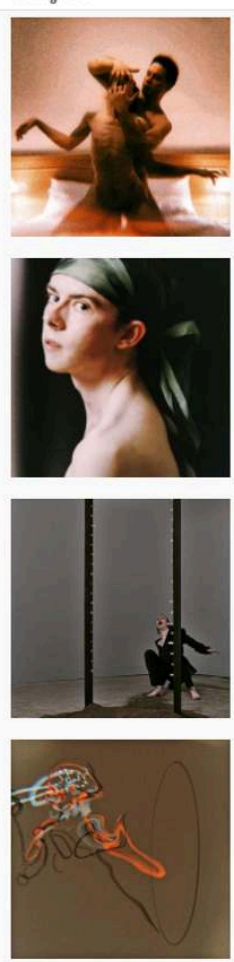
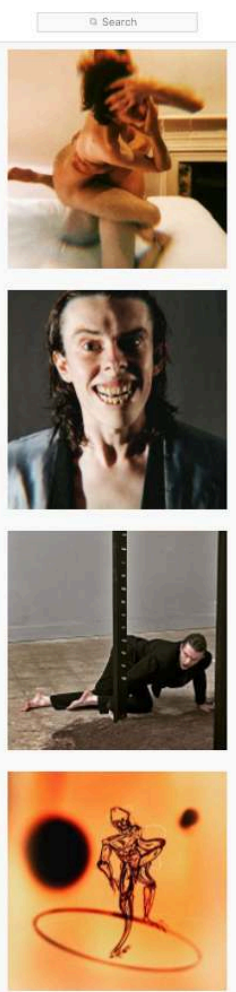

ก
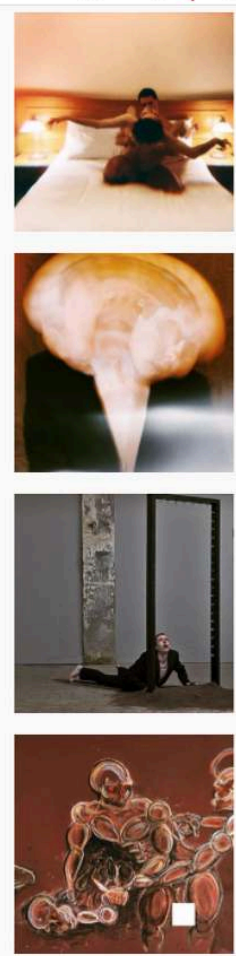

(c)www.instagram.com/day.magee/_(page accessed 20 th of November 2020).

Reading Magee's work, across their Instagram profile, their practice of selfperformance fluidly moves across media forms, revealing a critical practice of not only making but also becoming images. In a photograph produced for an on-line magazine article intended as a profile of the artist, Magee assumes a classical portrait pose, shoulders sideways, their head turning back to gaze at the camera. They wear a dusk green headscarf. It has a satin sheen in the painterly light and the image is strongly 
reminiscent of Vermeer's Seventeenth Century Girl with a Pearl Earring (c 1665) (Figure 17). The scarf, an androgenising device, masks the hair as signifier of sexed identity and is also historically and culturally ambiguous. This is both a portrait of Magee as artist and a portrait of the artist as muse, a painting and photograph, feminised and masculinised. Their on-going project of the body, as a nonbinary genderqueer identified subject, is manifested as a critical undecidability of the imagery across their practice. Jones asserts that such gender indeterminacy radically disrupts understandings both of gender as binary and subjectivity itself as fixed (In-Between Subjects 24). That is, the subject who understands and lives themselves as across or between genders demonstrates the contingency of all subjectivity.

Magee's practice mobilises such radical 'inbetweenness' sliding fluidly across media, producing a highly transmedial practice (In Between Subjects 24). Chen and olivares assert that whilst transmedia corporate products may tell narratives across multiple forms of media as a means to achieve wider audiences and greater profits, critical transmedia approaches can reclaim the subversive potential of hybrid media (246). They assert "Trans and genderqueer rebels mobilize transmedia" as critical form that "exploits, undermines, and overwrites corporate uses of the same term" (246-7). This can be conceived as a kind of trans*media in which the asterisk "modifies the meaning of transitivity by refusing to situate transition in relation to a destination, a final form, a specific shape, or an established configuration of desire and identity" (Halberstam, Trans*). This reclaims the hybridity of media as trans*. In other words, not only across and between platforms but across standpoints and genders and ontologies.

Figure 18. MAGEE, Day. Single album cover, Oakdene Avenue. Music single. 2020.

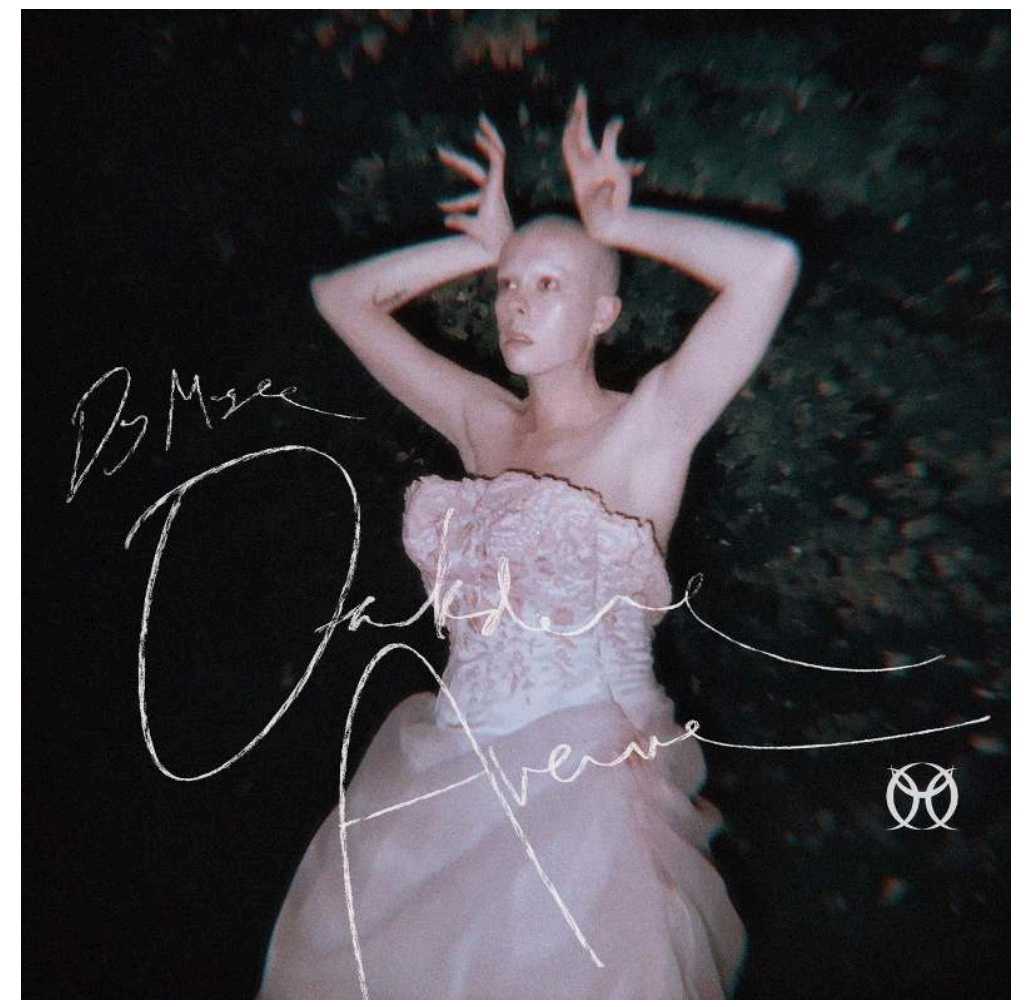

(Chttps://www.youtube.com/watch?v=6Re8FTYzucY\&feature=emb_logo. (page accessed $14^{\text {th }}$ December 2020) 
In this way, Magee's work produces subjectivity as fluid, hybrid and contingent as it moves across and between genders and media. This is seen in their release of a music album and video, which I read as an extension of their performance art practice and a play on form. In the video for the single Oakdene Avenue, they appear bald-headed and porcelain skinned, in a pale pink ballgown (Figure 18). Gyrating their hips, the dress undone to the waist reveals their flat-chestedness, as they move between elegant debutante and fierce Gollum-like creature. The surface of the video also gyrates, as if summoned through the swing of their hips. It warps Magee's body and face into ever distorted and disorientating forms, in time to the music. This work provokes what Sarah Ahmed describes as a "queer moment of disorientation" that enables us to view from another perspective and through which "we might even find joy and excitement in the horror" (Ahmed, Queer Phenomenology 4). The fixing, absorbing gaze, draws me into a queer time, space and embodied subjectivity that is at once strange and beautiful. It is a compelling, fascinating non-normativity which allows me to sit with, and become open to, this Otherness. The synchronous, yet distorting gyration of the body and the image forcefully provokes a reconsideration of the body-machine interrelation. Magee's queer disorientation conjures a kinship with the machine, that enables a reconceptualization of relational interconnectedness, not only through but with digital technologies. It is a kind of "machinic kinship" through which posthumanist conceptualisations urge us to move beyond a human centric view of our relationship with machines, in order to "look at the interlocking of technical and biological processes of mediation" (Zyliknsa 151; Kember and Zylinska xiii). Through an ambiguous genderqueer ontology and disorientating queer time and warped spatiality, the work conjures the kind of "monstrous and illegitimate" cyborg unity that Haraway envisions "in which people are not afraid of their joint kinship with animals and machines, not afraid of permanently partial identities and contradictory standpoints" (15-16).

Figure 19. MAGEE, Day. Adore/Unprotected. Still from music video. 2020.

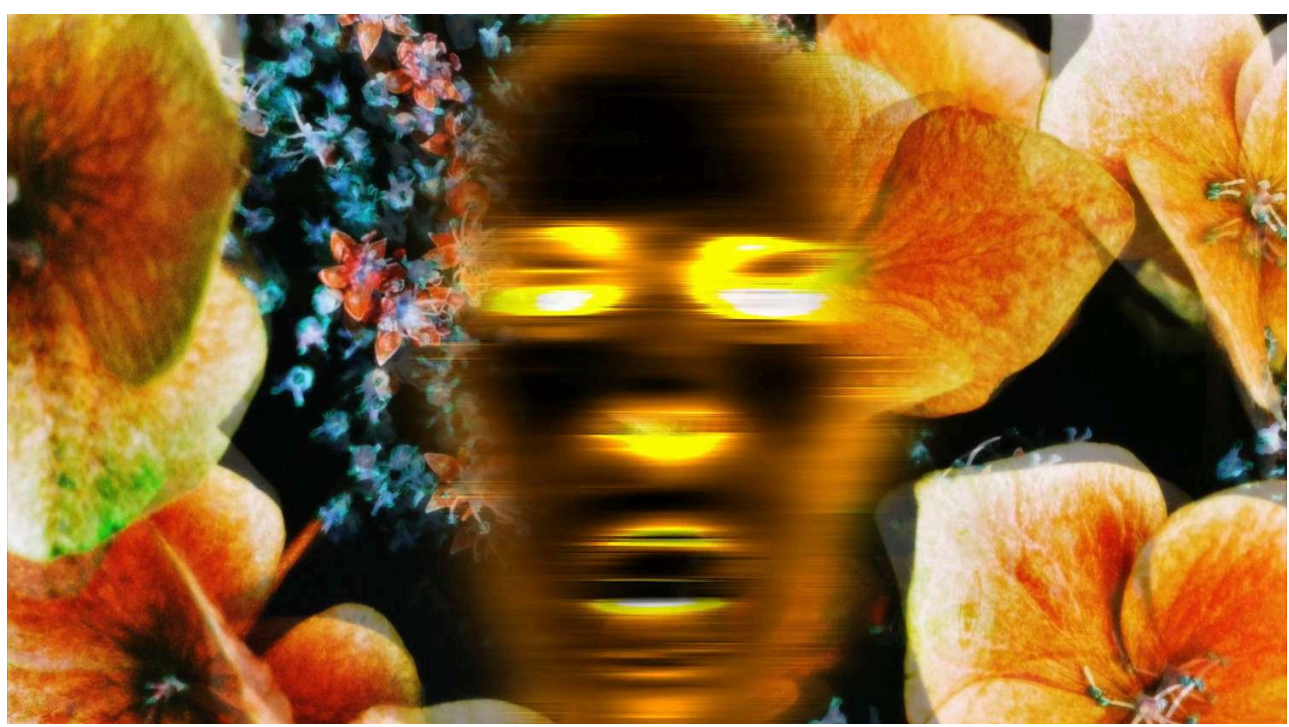

Chttps://www.youtube.com/watch?v=gfqLZX6Q-qA\&feature=emb_imp_woyt (page accessed 14 $4^{\text {th }}$ December 2020). 
digital kinship is further explored in another music video, Adore/Unprotected (2020). Magee's face floats like a celestial being, a disintegrating supernova against a processual, post-processed floral dreamscape (Figure 19). It is a radical fantasy of disintegration into a rolling cascade of digital colour gradients, which is narrated as an ecstatic self-destruction. They understand their chronic pain as an "internalised homophobia" and this work brings the viewer into their conflicted desire for selfinfection as a coping mechanism: "love, unprotected and infected, fill me with your love.". This work sits somewhere between a queer utopian horizon of potentiality, and an ecstatic fantasy of annihilation, mobilising queer cultures that "make communities in relation to risk, disease, infection and death" in order to reject heteronormative narratives of reproductive longevity. (Munoz 1; Halberstam In a Queer Time and Place 2). In the work the genderqueer subject disintegrates into their own fantasy: through their accession into the digital realm, they become a group of pixels tenuously held together, floating on the edge of subjectivity.

Through this pair of music/video works, the embodied genderqueer subject, is both glamorously warped and self-destructively fantastical. Employing mediation as means of dealing with trauma pushes the subject's understanding of themselves as embodied to the point of dissolution. Indeed, across the practice, mediation is employed as 'postprocessing' that attempts to reconcile lived traumatic experience and, in doing so, interrogates and challenges embodied subjectivity and its affective inter-circuitry with the digital. The echoes and vibrations of the voice, and the beats and movements of the body in digital rhythms across live and digital performance works are a seeking of the self through the constant re-telling of autobiographical narrative. Magee surfaces the omnipresent yet disavowed mediation of subjectivity in networked digital media, and utilises this instrument of digital economies as a tool in the on-going quest for selftransformation. Thus they both draw attention to and upend the autobiographical impulse produced through social media: the game of self-narration through the networked image that seeks to manifest a version of the self. Yet Magee's image-craft and curation is a more fluid conversation between self, image and embodied experience (of gendered pain). The work mobilises not only the performance artwork, but the self as having a 'viral ontology': a self-destructive desire to be infected and infectious, that employs the digital to seek release from pain as an ongoing act through which the self is iteratively performed.

\section{Conclusion}

41 I have read these artists' practices across live and digital spaces in order to consider how performance art more generally, like much of contemporary life "under the image", rubs up against the digital and is reframed in digital flows and structures. This drew on performance scholarship such as Kathy O'Dell and Amelia Jones, who explicitly mobilise the act of 'reading' performance practices to reveal their forms and frames as meaning-making, to consider the kinds of knowledge they produce, and to understand such readings as always already subjectively positioned and historically and culturally contingent. I have done this in order to make visible some of the ways in which we read performance through digital technologies and frames, particularly social media, as the dominant mode in which such artworks are now received. I have also considered how in this context, the digital as part of daily life, 'rubs off on' performance, and how this 
speaks to subjectivity as understood "under the image", through critical strategies of queer and genderqueerness (Harbison, 15).

Both Fay and Magee's practices have live performance at their core, activating the relational and charged present of encounters with an audience. Yet, the image features just as strongly, through established forms such as documentation of live artworks and performances specifically for the camera, as well as practices emergent through digital media. The image is a device that brings the concerns of their practice into contact with digital technologies, networks, frames and effects: the digital brushes against and seeps into their work. The digital in Magee's work invades the body as a black hole, which signifies both the body bearing the oppression of gender persecution and a transformation seeking visualisation of the invisible pain of trauma. These works are open to readings of the body marked by the dominant heterosexual narrative and of a subject recuperating agency from within their gendered pain. Other works strengthen the reading of Magee's use of performance as catharsis through acts of grieving, as well as their 'machinic kinship', and mobilisation of mediation for its transformative potential: acts that re-narrativize the self and reclaim lived experiences of pain. In video performance works Fay's use of digital processing causes the body to be danced by the image: made at once artificial and flesh and blood. The digital is used to deploy a celebratory out-of-placeness which reclaims the Otherness of the queer subject. Magee too employs the digital as transcendent, a fantasy of disintegration in a technicolour digital realm: pushing the radical indeterminacy of gender-queerness to the point of dissolution. Whilst employing the intangible codes and artificiality of digital effects, at the same time Fay and Magee bring the sensibilities of live performance practitioners to bear, representing queerness as being embodied, fleshy, tender and imbued with pathos.

Reading both these practices through social media enables an expanded understanding of their concerns. This is not simply through ease of access but in their understanding and use of social media as form, as a space in which public/private and embodied/ symbolic selves intersect. Fay uses both performance and social documentary practices, mobilising the structure of social media as a processual unfolding of the self through inter-relational encounters over time, which both positions him as queer Other and also queers the significations of the encountered objects/spaces/others. Magee mobilises the confessional nature of social media to present an unshrinkingly explicitness: presenting raw-emotional disclosure and explicit sexuality, both challenging and strikingly vulnerable through the auto-biographical, public/private digital space. By negotiating how their practices operate and are read within the social media profile account as framing device, their work demonstrates an appropriation of a digital form designed to instrumentalise, both the image and subjectivity.

Both artists utilise the digital image and its effects to envision queer futurities. Deploying strategies of genderqueer subjectivity as indeterminate and embodied kinship with the machinic Other. Magee's practice speaks to the complex, contradictory and affective interplay of bodies and the networked digital image, as a relation of both pleasures and pains. They perform a digital subjectivity, so fluid that it hovers on the point of ecstatic disintegration. Fay reimagines the earthy masculinities of Irish identities, untethering them from the heteronormative reproductive logic that underpins national narratives. Performing the queer subject as both in and out of place, he refuses to posit an alternative fixed sense of belonging. Instead he mobilises 
human and non-human kinship and reimagines social relations as organised through an identification with otherness.

Whilst these works are not explicitly about prosumerism, or digital cultures, siting their image making practices across both art and social/media contexts, Fay and Magee bring their critical embodied practices into dialogue with discourses at play within digital and social media. In this way they draw attention to the constant performing of the body as cultural image, through digital technologies. If performance art has a viral ontology, its meaning is understood as performed iteratively, over-time through readings, re-readings and re-contextualizations of the original event. The work of these artists demonstrates how performance practices can enable understandings of the self as also iteratively produced, by critically revealing and queering the role of the digital image and its frames, in this iterative meaning - and subject - making.

BIBLIOGRAPHY

\section{Works cited}

AHMED, Sarah. What's the Use? Durham and London: Duke University Press, 2019.

AHMED, Sarah. Queer Phenomenology. Durham and London: Duke University Press, 2006.

AUSLANDER, Phillip. Liveness: Performance in a Mediatized Culture. 1999. Oxon and New York: Routledge, 2008.

BEATTY, Aidan. Masculinity and Power in Irish Nationalism, 1884-1938. London: Palgrave Macmillan, 2016.

BEAVEN Kirstie. Performance Art. The Happening. https://www.tate.org.uk/art/art-terms/h/ happening/happening, n.d. (accessed 01/12/20)

BEDFORD, Christopher. “The Viral Ontology of Performance”. Eds. Jones, Amelia and Heathfield, Adrian. Perform, Repeat, Record: Live Art in History. Bristol: Intellect, 2012. 77-87.

BERLANT, Lauren and Michael WARNER. Sex in Public. Critical Inquiry, 24: 2, Intimacy (Winter, 1998). 547-566.

BRIGHT, Sarah. Auto Focus: The Self Portrait in Contemporary Photography. London: Thames and Hudson, 2010.

CHATFIELD, Tom. How to Thrive in the Digital Age. London: MacMillan. 2012.

CHEN, Jian and Lissette OLIVARES. Transmedia. TSQ: Transgender Studies Quarterly. 1:1-2 (2014). 245-248.

CARUTH, Cathy. Trauma: Explorations in Memory. 1995. Baltimore and London:The Johns Hopkins University Press.

COWAN, T. L. "The Internet of Bawdies: Transmedial Drag and the Onlining of Trans-feminist and Queer Performance Archives, a Workshop Essay”. First Monday, 23: 7 - 2 (2018). 
www.firstmonday.org/ojs/index.php/fm/article/download/9256/7459. (accessed 11/11/21) FANTHOME, Christine. 2006. "The Influence and Treatment of Autobiography In confessional Art: Observations on Tracey Emin's Feature Film ‘Top Spot””. Biography, 29:1 (2006): 30-42.

Genderqueer. At: https://www.lexico.com/en/definition/genderqueer, n.d. (accessed 31/01/21). HALBERSTAM, Jack. Trans* A Quick and Quirky Account of Gender Variability. University of California Press, 2018.

HALBERSTAM, Jack. In a Queer Time and Place: Transgender Bodies, Subcultural Lives. 2005. New York and London: New York University Press.

HARAWAY, Donna. "A Cyborg Manifesto: Science, Technology, and Socialist Feminism in the Late Twentieth Century". Simians, Cyborgs and Women: The Reinvention of Nature. New York; Routledge, 1991. 149-181

HARBISON, Isobel. Performing Image. Cambridge, MA. The MIT Press, 2019.

HARRIS, Alice. “These Objects Call us Back: Kinship Materiality in Native America”. Inappropriate Bodies: Art, Design and Maternity. Eds. Epp Buller, Rachel and Reeve, Charles. Bradford: Demeter Press, 2019. 213-216.

JONES, Amelia. In-Between Subjects: A Critical Genealogy of Queer Performance. London and New York: Routledge, 2020.

JONES, Amelia. "Performing the Wounded Body: Pain, Affect and the Radical Relationality of Meaning". Parallax, 15:4 (2009). 45-67.

JONES, Amelia. "Presence in Absentia: Experiencing Performance as Documentation". Art Journal, 56: 4 (1997). 11-18.

KEELING, Kara.“Queer OS”. Cinema Journal, 53: 2 (Winter 2014). 152-157.

KEMBER, Sarah and Joanna ZYLINSKA. Life After New Media: Mediation as a Vital Process. Cambridge MA and London: MIT Press, 2012.

KELLNER, Douglas. "Jean Baudrillard". The Stanford Encyclopedia of Philosophy. (Winter 2020 Edition). Ed. Edward N. Zalta. https://plato.stanford.edu/archives/win2020/entries/baudrillard/ (accessed 31/01/21).

LAMBERT, Alex. 2015. "Intimacy and social capital on Facebook: Beyond the psychological perspective”. New Media \& Society, 18:11 (2016). 2559-75.

MUNOZ, Jose, Esteban. Cruising Utopia: The Then and There of Queer Futurity. 2009. New York: New York University Press. 2019.

O'DELL, Kathy. Contract with the Skin: Masochism, Performance Art and the 1970s. Minneapolis: University of Minneapolis Press, 1998.

O’BRIEN, Martin. "Performing Chronic: Chronic Illness and Endurance". Performance Research: A Journal of the Performing Arts. 19: 4 (2014). 54-63.

O'RIORDAN, Kate “Queer Digital Cultures”. The Cambridge Companion To Queer Studies. Cambridge University Press, 2020. Ed. Somerville, Siobhan.

PHELAN, Peggy. Unmarked: The Politics of Performance. 1993. London: Routledge, 2005.

PRICE, Graham. Quite an Other Thing: Recent Texts in 'Irish Queer Studies'. Irish University Review 43.1 (2013). 222-233.

RYAN, Fergus. Ireland's Marriage Referendum: A Constitutional Perspective. DPCE Online, 2015-2. 
SANDAHL, Carrie. 2000. "Bob Flanagan: Taking It Like a Man". Journal of Dramatic Theory and Criticism, 15:1 (2000). 97-104.

SHALSON, Lara. Performing Endurance: Art and Politics since 1960. Cambridge University Press, 2018.

SIMULA, Brandy L. "Queer Utopias in Painful Spaces: BDSM Participants'

InterrelationalResistance to Heteronormativity and Gender Regulation". Queer Utopias, Queer Futurity, and Potentiality in Quotidian Practice. Ed. Jones, Angela. New York: Palgrave Macmillan, 2013. 71-100.

Situationist International. https://www.tate.org.uk/art/art-terms/s/situationist-international, n.d. (accessed 31/01/21).

SONTAG, Susan. Regarding the Pain of Others. New York: Picador, 2004.

STYKER, Susan.“(De)Subjugated Knowledges: An Introduction to Transgender Studies”. The Transgender Studies Reader. Eds. Styker, Susan and Whittle, Stephen. London and New York: Routledge, 2006

TERRAS, M M. Ramsay, J. and E. A. BOYLE. "Digital Media Production and Identity: Insights from a Psychological Perspective”. E-Learning and Digital Media 12:2 (2015): 128-146.

THORNE, Nat., Andrew KAM-TUCK-YIP, Walter Pierre BOUMAN, Ellen MARSHALL and Jon ARCELUS. "The Terminology of Identities Between, Outside and Beyond the Gender Binary - A Systematic Review." International Journal of Transgenderism 20:2-3 (2019) 138-154.

WALSH, Fintan. Queer Performance and Contemporary Ireland: Dissent and Disorientation. London and New Work: Palgrave Macmillan, 2016.

WESTERMAN, Jonah. 2015. "Between Action and Image: Performance as 'Inframedium”". Tate Research Feature. January 2015. https://www.tate.org.uk/research/features/between-action-andimage (accessed 31/01/21).

ZYLINSKA, Joanna. “The Creative Power of Nonhuman Photograph”. Photographic Powers. Eds. Elo, Mika \& Karo, Marko. Helsinki: Aalto University, 2015. 132-154.

\section{ABSTRACTS}

In digital age there is a "reciprocity of images and bodies during regular, multiple and multisited encounters." (Harbison 16). Westerman asserts performance as 'inframedium', that is ontologically situated between life and image (Westerman n.p.). As such it is well placed to critically address the production of normative subjectivities, in the context of a radically accelerated, embodied relationship to the image through digital media. This paper will explore the work of two contemporary Irish queer/genderqueer artists, Francis Fay and Day Magee, examining their work across live and digital practice. Foregrounding my own acts of reading (after Jones), I seek to mobilise the operation of taken for granted digital/social media formats in the production of meaning. I will examine how these artists utilise the ontology of performance practice in a digital age, to posit queer futurities that conjure alternative social relations, and resist and challenge normative subjectivity as fixed through heterosexual logics.

A l'ère du numérique, on constate "une réciprocité des images et des corps au cours de rencontres régulières, multiples et multisites » (Harbison 16). Westerman situe la performance comme « inframedium », c'est-à-dire ontologiquement placée entre la vie et l'image (Westerman, n.p.). A ce titre, elle est pertinemment située pour émettre un jugement critique sur la production de subjectivités normatives, dans le contexte d'une relation à l'image par le 
truchement du médium numérique radicalement accélérée et incarnée. Cet article analysera les travaux de deux artistes irlandais queer/genderqueer, Francis Fay et Day Magee, par le prisme de leurs pratiques scéniques et numériques. Utilisant ma propre lecture (dans le sillage de Jones), je cherche à mettre en avant le fait que les formats numériques et ceux des réseaux sociaux sont considérés comme acquis dans la production du sens. J'étudierai comment ces artistes se servent de l'ontologie de la pratique de la performance à l'ère numérique, pour explorer des futurités queer faisant appel à des relations sociales alternatives, qui à la fois résistent à la subjectivité normative et la remettent en question telle qu'elle est imposée par les logiques hétérosexuelles.

\section{INDEX}

Keywords: performance art, live art, queer, genderqueer, queer futurity, Irish Identity, subjectivity, digital image, digital media, social media, Instagram

Mots-clés: art performatif, art vivant, queer, genderqueer, futurité queer, identité irlandaise, subjectivité, image numérique, media numérique, réseaux sociaux, Instagram

\section{AUTHOR}

\section{KATHERINE NOLAN}

Technological University Dublin

Dr. Katherine Nolan is an artist, lecturer and researcher specializing in gender and new media. With a particular focus on tensions between the experiential and the spectacular body, her research investigates gender, identity and desire in the context of digital cultures. Her artistic practice is primarily performance and lens-based media, and she has exhibited internationally in Europe, America and Asia. She regularly curates with MART Gallery and Studios and Livestock Performance Art Platform. Recent exhibitions include The Mistress of the Mantle solo exhibition at MART Dublin and group shows at LACE Los Angeles, Supermarket Art Fair Stockholm and Future Histories at Kilmainham Gaol, Dublin. Recent research papers include Fear of Missing Out: Performance Art Through the Lens of Participatory Culture in the International Journal of Performance Arts and Digital Media (2021): The 'Stuff' of Life; Material Play and Performance in Digital Video Cultures and Performance Art Practice at the Association of Internet Researchers Annual Conference (2020); and Fictioning the Past: Performing the Self as the Mistress of the Mantle in Post-Catholic Ireland at the Irish Society for Theatre Research Annual Conference (2019). She Lectures in Creative Digital Media in Technological University Dublin. 